\title{
Osmanlı Minyatürlerinde Sefer Vasıtaları (16.-18. Yüzyıllar)
}

\section{Expedition Vehicles in the Ottoman Miniatures $\left(16^{\text {th }}-18^{\text {th }}\right.$ Centuries $)$}

\author{
Ela Taş* (i), Aslıhan Erdoğan** (i)
}

\section{Öz}

Osmanlı́nın sınır beyliğinden dünya imparatorluğuna dönüşmesinin temelinde, izlediği siyasi anlayışın yanı sıra askerî alanda atmış olduğu adımların da önemli bir payı vardır. Kuruluş aşamasında, atlı birliklerle gerçekleştirilen akınlar şeklinde kendini gösteren savaşların devletin büyümesine paralel olarak düzenli ordularla gerçekleştirildiği bilinmektedir. Yayılımcı siyaset anlayışı sebebi ile çok sayıda sefer düzenleyen Osmanlı Devleti’nin seferler sonucunda arzu ettiği zafere ulaşmasının şartlarından biri de ordu için gerekli olan yanıcı ve patlayıcı maddeler, mutfak malzemeleri, erzak, çeşitli araç gereçler gibi kaynaklarda zikredilen teçhizatın teminive bunların savaşın gerçekleştirileceği bölgeye başarılı bir şekilde sevk edilmesidir. İkmal ve iaşe kavramları ile karşılık bulan unsurların naklinde, kara ve deniz yolunda kullanılan sefer vasıtalarından istifade edildiği Osmanlı tarihini konu alan çalışmalardan ve padişahların hayatlarını içeren yazma eserlerin minyatürlerinden izlenebilmektedir. Bu çalışmanın amacı, Osmanlı́nın gerçekleştirmiş olduğu seferlerde kullandığı vasıtaları, tarih konulu yazma eser minyatürleri üzerinden açıklamak ve gerçekçi yaklaşımla ortaya konan tasvirlerin belgelemedeki önemlerinin anlaşılmasını sağlamaktır. Çalışmada, tarihi kaynaklarda zikredilen at, katır, deve, fil, top arabası gibi kara; kadırga, baştarda, kalyon, mavna, barça gibi deniz yolunda kullanılan vasıtalar, tarihî olaylar ve minyatürler çerçevesinde ifade edilmiştir. Çalışma kapsamında, Osmanlı seferlerini içeren ve 16.-18. yüzyıllar arasına tarihlendirilen yazma eserlerdeki vasıta tasvirleri üzerinden değerlendirme yapılmıştır.

\section{Anahtar Kelimeler}

Osmanlı, minyatür, tasvir, sefer, vasıta

\begin{abstract}
The strides made in military issues as well as the political considerations played major roles in the transformation of the Ottoman state from a small-scale seigniory into a world empire. It is well-known that the conquests made by the mounted troops during the establishment period were sustained with regular armies in parallel to the extension of the state. While the Ottoman state launched expeditions for the sake of imperialistic political considerations, one of the necessities to gain the desired outcome was the necessary equipment for the armies and the successful dispatch of such materials to the battlefields. In this regard, over-land and naval expedition vehicles were utilized during the dispatch of these components. It is also possible to determine the vehicles used by the Ottoman Empire in the expeditions through various miniature manuscripts from this period. As is widely known, miniatures are created to fit within the page margins in order to illuminate the contents of the manuscripts. Thus, the purpose of this study is to discuss the over-land vehicles (e.g., horses, mules, camels, elephants, gun carriages, and chariots) and naval vehicles (e.g., galiots, bastardas, galleons, lighters, and barges), which are mentioned in the miniatures that depict the Ottoman expeditions and express the importance of these events. The vehicles depicted in these manuscripts date back to the $16^{\text {th }}-18^{\text {th }}$ centuries, which include the Ottoman expeditions evaluated in this research.
\end{abstract}

\section{Keywords}

Ottoman, miniatures, depiction, expeditions, vehicles

* Sorumlu Yazar: Ela Taş (Doç. Dr.), Sakarya Üniversitesi, Fen Edebiyat Fakültesi Sanat Tarihi Bölümü, Sakarya, Türkiye. E-posta: elatas@sakarya.edu.tr, ORCID: 0000-0003-1647-7252

** Aslıhan Erdoğan (Yüksek Lisans Öğrencisi), Sakarya Üniversitesi, Sosyal Bilimler Enstitüsü, Sanat Tarihi Anabilim Dalı, Sakarya, Türkiye. E-posta: aslig.erdogan@gmail.com, ORCID: 0000-0001-7847-1265

Atıf: Tas, Ela ve Erdogan, Aslihan. “Osmanlı Minyatürlerinde Sefer Vasıtaları (16.-18. Yüzyıllar)." Art-Sanat, 16(2021): 529-555. https://doi.org/10.26650/artsanat.2021.16.0018 


\section{Extended Summary}

The key to the success of the Ottoman state, which constantly expanded policies and organized numerous expeditions, was having a well-organized army. It is also well-known that the state took various measures in order to endure and conquer its enemies. The supply and transportation of necessary materials during these expeditions were among these measures. In addition, over-land and naval expedition vehicles were utilized during the dispatch of these components.

Specifically, the over-land vehicles in the Ottoman expeditions fell into two groups: draught animals and drays. Mount and draught animals were the most frequently used forms of transportation in these expeditions. Horses were also the most important in terms of military ordnance, since they were used both as mount and draught animals. Besides horses, other animals, such as mules, camels, and elephants, were used in the dispatch of various supplies, including victuals, weapons, and tents. Meanwhile, carthorses, water buffalos, and cattle were used in the dispatch of gun carriages and drays. However, it is well-known that the courtiers and military coteries preferred horses as expedition vehicles, not carriages, since they caused somnolence. Moreover, non-motorized carriages were used in the transportation of patients and the wounded as well as in significant occasions such as funerary transportation and the dispatch of commodities, victuals, and war equipment.

The Ottomans, extending its sovereign area and taking important steps to become a world empire, intended to sustain the holy war activities via over-land and naval routes. Thus, they built shipyards in regional centers, such as Edincik, Karamürsel, İzmit, and Gelibolu, where the repair of old ships and the building of new ones were performed in order to develop the fleet. While the Ottoman fleet was actively a raider fleet in the early period (i.e., from the second half of the $15^{\text {th }}$ century), resulting in the conquest of Istanbul and its important geopolitical position, it was possible for the Ottoman navy to take the necessary steps to establish an imperial fleet. In addition, to the previously built shipyards, the Galata shipyard (Tersane-i Amire) was established during the Sultan Mehmed II era and finalized by Sultan Selim I. On the condition that the locations of the battlefields were appropriate, the sea transportation and exploration vehicles under the groups of oared, sailing, and steam vehicles were built and used for the transportation of equipment and subsistence.

It is also possible to determine the vehicles used by the Ottoman Empire in the expeditions through various miniature manuscripts from this period. As is widely known, miniatures are made to fit within the page margins in order to illuminate the contents of the manuscripts. In this regard, the demand of Ottoman Sultans on specifically recording their own events or those of their ancestors has fostered Sultanic historiography, i.e., the tradition of recording history in the Ottoman world. 
Besides their literary worth, the Sultanic historiographies regarding the lives, expeditions, and successes of the Sultans provide important information. For example, the Ottoman state used every means available to gain the desired outcome in the wars, which can be observed in the details of the miniatures, especially the depictions regarding the order, war tactics, apparel, and weapons of the Ottoman army. The Ottoman government also had the ability to outfit a vast number of soldiers, which was the mission of the armorer guild. Meanwhile, the timariots, who joined the expedition from other states, also brought their own equipment. In this case, inflammable and explosive materials, kitchenware, various tools, ground clothes, and musical instruments were such equipment mentioned in the sources.

In order to ensure the security of the army during the expeditions, such equipment was transported with both over-land vehicles (e.g., horses, mules, camels, elephants, gun carriages, and chariots) and naval vehicles (e.g., galiots, bastardas, galleons, lighters, and barges), instead of having the soldiers transport the equipment themselves. The aforementioned vehicles can be observed in the miniatures of the following literary works on Ottoman expeditions: Feridun Ahmed Bey's Nüzhetü'l-esrâri'l-ahbar der Sefer-i Sigetvar, Seyyid Lokman's Şehinşehnâme II, Hünernâme and Zafernâme, Ârifi Fethullah Çelebi's Süleymannâme, Dal Mehmed Çelebi's as known as Âsafî's Şecaâtnâme, Matrakçı Nasuh's Târîh-i Feth-i Şikloş, Estergon and İstolni Belgrad and adversaria of a sailor named Hasan Kurdi, Keyfìyet-i Russiyye.

Thus, the purpose of this study is to discuss the over-land vehicles and naval vehicles, which are mentioned in the miniatures that depict the Ottoman expeditions and express the importance of these events. The vehicles depicted in these manuscripts date back to the $16^{\text {th }}-18^{\text {th }}$ centuries, which include the Ottoman expeditions evaluated in this research. 


\section{Giriş}

Evrensel bir devlet olmayı hedefleyen Osmanlı, bu uğurda, Anadolu ve Rumeli yönlerine sayısız sefer gerçekleştirmiştir. Yüzlerce kilometrelik mesafelerde, sayısı yüz binlerle ifade edilen neferler ile yürütülen seferlerin zaferle sonuçlanması için devletin tüm imkânlarının değerlendirildiği bilinmektedir. Zor şartlar altında sürdürülen seferlerin başarıyla gerçekleştirilmesinin temelinde belirli bir disiplin çerçevesinde yürütülen hazırlık aşaması vardır. Söz konusu süreçte padişah yönetiminde bir meclisin toplandığı, ordunun ve hazinenin durumun görüşüldüğ̈ ve sefer düzenlenecek yöndeki şehirlerde bulunan Osmanlı yöneticileriyle iletişime geçilerek ilgili güzergâhlarda gerekli inşa ve onarım faaliyetlerinin yapılmasının istendiği bilinmektedir. Bu çalışmalar arasında yolların temizlenmesi, engellerin kaldırılması, köprü tamiri ve inşası, kale onarımları... vs. saymak mümkündür. ${ }^{1}$ Hazırlık sürecinin önemli aşamalarından birini de savaşların kazanılmasında en etkin rolü oynayacak olan ordunun ihtiyaçlarının karşılanması oluşturmaktadır. Bilindiği gibi sefer sırasında orduyu oluşturan bölükler; erzak, mühimmat, eşya, alet-edevat gibi gereçlere ihtiyaç duymakta ve hepsi birden techizat-1 seferiyye ${ }^{2}$ olarak ifade edilmektedir. Osmanlı yönetiminin, kalabalık sayıda askeri donatmada büyük bir yeteneğe sahip olduğu ${ }^{3}$ ve bunların temininin cebeci ocağının ${ }^{4}$ görevi kapsamında değerlendirildiği bilinmektedir. Yanıcı-patlayıcı maddeler, erzaklar, mutfak malzemeleri, yaygılar ${ }^{5}$, müzik aletleri ${ }^{6}$ kaynaklarda zikredilen donatılar arasındadır. Osmanlı literatüründe iaşe ve ikmal kavramlar1 ${ }^{7}$ ile karşılık bulan bu unsurlar, ordunun güvenliğini sağlamak ve askeri yormamak gibi sebeplerle çeşitli vasıtalar ile sefer düzenlenecek bölgeye intikal ettirilmiştir.

Osmanlı sultanlarının yapmış oldukları seferleri konu alan yazma eserler; ordunun düzeni, savaş taktikleri, kullandığı silah ve donatılar hakkında fikir veren yazınsal kısmın yanı sıra içeriklerinin daha anlaşı1ır kılınması amacıyla eklenen minyatürler de barındırır. Söz konusu tasvirlerde, Osmanlı seferlerinde ihtiyaç duyulan iaşe ve ikmalin, sefer bölgesine naklinde kullanılan vasıtalarında işlendiği görülmektedir. Os-

1 M. Yaşar Ertaş, “Osmanlı Devletinde Sefer Organizasyonu,” Osmanlı, c. 6 (Ankara: Yeni Türkiye Yayınları, 1999), 590.

2 M. Zeki Pakalın, Tarih Deyimleri ve Terimleri Sözlüğü, c. 3 (İstanbul: MEB Basımevi, 1972), 433.

3 Feridun Emecen ve Erhan Afyoncu, Savaşıı Sultanları I, ed. Coşkun Yılmaz (İstanbul: Bilge Yayım, 2018), 82.

4 15. Yüzyıldan itibaren varlık gösterdiği kabul edilen cebeci ocağı, Osmanlı ordusu için gerekli olan silah ve teçhizatı sağlamak, bunların tamirini yapmak ve savaş sırasında orduya dağıtımını yapmakla görevliydi. Detaylı bilgi için bk. Yasemin Kılıı̧arslan, "Cebeci," TDV İslam Ansiklopedisi, c. 7 (İstanbul: Türkiye Diyanet Vakfi Yayınları, 1993), 182.

5 Mehmet Canatar, "Muhasara," TDV İslam Ansiklopedisi, c. 31 (İstanbul: Türkiye Diyanet Vakfı Yayınları, 2006), 12.

6 Uğur Kurtaran, “Osmanlı Seferlerinde Organizasyon ve Lojistik,” Turkish Studies 7/4 (2012), 2281.

7 Kurtaran, "Osmanlı Seferlerinde Organizasyon ve Lojistik," 2270. 
manlının seferlerini konu alan minyatürlerle ilgili çok sayıda yayın ${ }^{8}$ olmakla birlikte, bu süreçte kullanılan sefer vasıtaları ile alakalı kapsamlı bir değerlendirme yapılmamıştır. Bu çalışmada, minyatürlerde tasvir edilen kara ve deniz yollarında kullanılan vasıtalar ele alınmıştır.

\section{Karayolunda Kullanılan Sefer Vasıtaları}

Osmanlılar, mevsimsel şartlara bağlı olarak karayolu üzerinden gerçekleştirdikleri seferlerde ${ }^{9}$, ikmal ve iaşenin sevkinde kullandıkları vasıtaları, hayvanlar ve arabalar şeklinde sınıflandırmak mümkündür.

\section{Hayvanlar}

İnsan yaşamını çeşitli açılardan kolaylaştıran hayvanların Osmanlı seferlerindeki önemi yadsınamaz. Ordunun en önemli ihtiyaçları arasında yer alan bu unsurların, binek aracı olarak kullanılmalarının yanı sıra sefere çıkılan andan varış noktasına kadar süren kara yolculuğunda, gıda ve konaklama ihtiyaçları (erzak, çadır vd.), silahlar ve teçhizatları içeren çoğu malzemenin sevkinde değerlendirildiği bilinmektedir. At, katır, deve, fil yük taşıma amacına hizmet ederken; topkeşan, manda ve sığır ise top ve yük arabalarının naklinde kullanılmıștır. ${ }^{10}$ Seferlerde kullanılan hayvanlar, binek ve yük hayvanları olarak iki gruba ayrılır.

\section{a. Binek hayvanları}

Türklerin, tarihsel süreçte geniş coğrafyalara yayılmasını sağlayan etkenler arasında iyi yetiştirilmiş ve hızlı koşan atlara sahip olmaları vardır. Herhangi bir bölgeye düzenlenecek akınlar sırasında geniş adımlar atabilen ve uzun süre koşabilen atların kullanıldığı ve bu tercihin, Osmanlılar zamanında da sürdürüldüğü bilinmektedir. Osmanlılar, Anadolu beyliklerinden devraldıkları at yetiştirme geleneğini devam ettirmişlerdir. Ordusu büyük ölçüde süvari birliğine dayanan Osmanlılar, Anadolu ve Rumeli'de bulunan çeşitli tavlalarda yetiştirdikleri atlar ile ordunun at ihtiyacını karşılamışlardır. ${ }^{11}$ Seferlerde belirleyici rol oynayan atlar, sipahilerin temel dayanağ

8 Makalede kullanılan görsellerle ilgili detaylı açıklamalar için bk. Zeynep Tarım Ertuğ, "The Depiction of Ceremonies In Ottoman Miniatures: Historical Recordor a Matter Of Protocol," Muqarnas: An Annual on the Visual Culture of theIslamic World 27 (2010); Şebnem Parladır, "Sigetvar Seferi Tarihi ve Nakkaş Osman," Sanat Tarihi Dergisi XVI/I (2007); Günhan Börekçi, Nüzhet-i Esrarü'l-Ahyar Der-Ahbar-ı Sefer-i Sigetvar, haz. Ahmet Arslantürk ve Günhan Börekçi (İstanbul: Zeytinburnu Belediyesi Kültür Yayınları, 2012); Banu Mahir, Osmanlı Minyatür Sanatı (İstanbul: Kabalcı Yayınevi, 2012); Serpil Bağcı vd., Osmanlı Resim Sanatı (Ankara: Kültür ve Turizm Bakanlığ1 Yayınları, 2012); Metin And, Osmanlı Tasvir Sanatları I: Minyatür (İstanbul: Yapı Kredi Yayınları, 2014); Mustafa Gürbüz Beydiz, Osmanlı Gemi Tasvirleri, (İstanbul: Kabalcı Yayınevi, 2013).

9 Rhoads Murphey, Osmanlı'da Ordu ve Savaş (1500-1700), çev. M. Tanju Akad (İstanbul: Homer Yayınevi, 2007), 42.

10 M. Yaşar Ertaş, “Osmanlı Devletinde Sefer Organizasyonu,” 594.

11 Faruk Sümer, Türklerde Atçılık ve Binicilik (İstanbul: Türk Dünyası Araştırmaları Vakfı, 1983), 2, 36. 
olmuştur. Önemli bir binek vasıtası olmasının yanı sıra haberleşme ağında, su ihtiyacı hizmetlerinde de atlardan yararlanılmış ancak yük nakliyesinde tercih edilmemiştir. ${ }^{12}$ Tahta çıkma ve kılıç kuşanma törenlerinde ata binilmesi de askeri kuvvet kaynağ 1 ve önemli bineklerden biri olarak görülmesiyle alakalıdır. ${ }^{13}$ Osmanlı minyatürlerinde atlar, av, sefer ve savaş sahnelerinde yoğun bir şekilde işlenmiştir.

Seferlerde binek hayvanı olarak atın kullanıldığını gösteren tasvirlerden biri, Seyyid Lokman'ın (öl. 1601) Hünernâme II (1589) adlı eserindeki Mohaç Savaş1 (1526) sahnesinde karşımıza çıkar. Minyatür, Osmanlı ordusunun haşmetini, disiplinini, savaş düzenini göstermesinin yanı sıra ordunun ağırlıklı olarak atlı birliklerden oluştuğunu göstermesi açısından önemlidir. Kompozisyonun merkezine konumlandırılan padişahın ve etrafına yerleştirilmiş onlarca süvarinin at üstünde oldukları ve her bir atın rahvan pozisyonda tasvir edildiği görülür. Ön plandaki çarpışma anında ise dörtnala durumda olan atlara yer verilmiştir. Bu yaklaşım, savaşma anının canlılığını yansıtmakla birlikte tarihi kaynaklarda değinildiği üzere çarpışmanın ilk olarak öncü kuvvetler arasında yaşandığını göstermesi açısından dikkat çekicidir. ${ }^{14}$ Onlarca atın tasvir edildiği minyatür, Özkoca'nın Evliya Çelebi'den aktardığı Osmanlı ordusunda 150 binden fazla atl ${ }^{15}$ olduğuna dair görüşü desteklemekte ve Osmanlıların binek hayvanı olarak attan istifade ettiğini yansıtmaktadır.
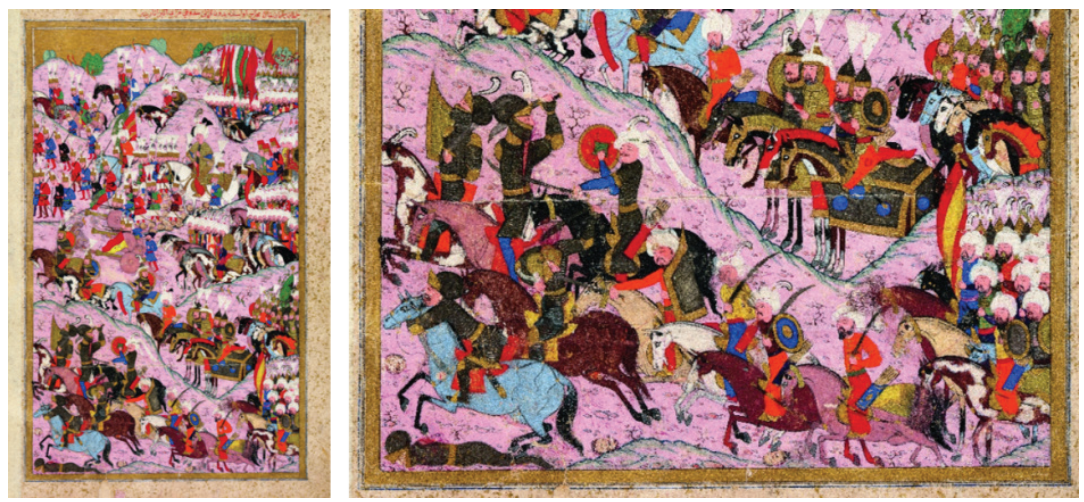

G. 1: At. Mohaç Savaş1, Seyyid Lokman, Hünernâme II. TSM, H. 1524, y.256b.

12 Yusuf Halaçoğlu, “At,” TDV İslam Ansiklopedisi, c. 4 (İstanbul: Türkiye Diyanet Vakfı Yayınları, 1991), 30.

13 Emel Esin, "Türk Kültüründe At ve Atçıllk," Türk Kültüründe At ve Çağdaş Atçıllk (İstanbul: Resim Matbaacılık, 1995), 58; Osman Turan, Türk Cihan Hâkimiyeti Mefkûresi Tarihi (İstanbul: Ötüken Yayınları, 2003), 27,131 .

14 Feridun Emecen, "Mohaç Muharebesi," İslam Ansiklopedisi, c. 30 (İstanbul: Türkiye Diyanet Vakfı Yayınları, 2005), 234.

15 Adnan Özkoca, "Türkiye'de At Yetiştiriciliği ve Sun'i Tohumlama Teknolojisi," Türk Kültüründe At ve Çağdaş Atçıllk, haz. Emine Gürsoy Naskali (İstanbul: Türkiye Jokey Kulübü Yayınları, 1995), 329. 


\section{b. Yük Hayvanları}

Karayoluyla gerçekleştirilen seferlerde ordunun güvenliğini sağlamak ve askeri yormamak gibi nedenlerle teçhizat ve erzak ${ }^{16}$, topkeşan, katır, deve, öküz, manda gibi hayvanlarla sevk edilmiştir. ${ }^{17}$ Osmanlı seferleriyle ilgili minyatürlerde at, deve, katır, fil gibi hayvanların tasvir edildiğini gözlemlemek mümkündür.

Seferlerde kullanılan yük hayvanlarından ilki devedir. Farsça şütür/üştür kelimesiyle ifade edilen deve, $250 \mathrm{~kg}$ yük taşıma kapasitesine sahiptir. Derin suları rahatlıkla geçebilmesi, bakımının kolaylığı, hava koşullarına uyum sağlaması, açlığa ve susuzluğa karşı dirençli olması ve hızlı koşması tercih edilme sebepleri arasındadır. Konargöçerlerden temin edilen develerle ${ }^{18}$, katarlar oluşturulur ${ }^{19}$ ve sefer teçhizatı yüklenirdi. Sayıları binlerle ifade edilen develer, yalnızca yük taşıma amaçlı kullanılmamış, aynı zamanda savaş sırasında birbirlerine zincirlerle bağlanarak ordunun önünde siper vazifesi görmüştür. I. Kosova (1389) ve II. Kosova (1444) savaşlarında bu uygulamayla karşılaşılmaktadır. ${ }^{20}$ Kaynaklardaki bilgiler, minyatürlerdeki deve tasvirleriyle eşleşmektedir.

Seyyid Lokman'ın (öl. 1601) Şehinşehnâme II'sindeki (1597-98), Ferhad Paşa'nın Revan Savaşı minyatürü (G. 2) konu kapsamında değerlendirilebilecek örnekler arasındadır. Çift sayfa tasarlanan tasvir, kapalı kompozisyon düzenine sahiptir. Solda Osmanlı askerlerinin şehre girmesiyle kaçışmakta olan halk, sağda ise Osmanlı ordusu yer alır. Bu sayfanın altında, bitişik nizamdaki deve katarları dikkat çekmektedir. Sırtlarına rulo biçimli, farklı renklerde yükler bindirilmiş olan develerin nakliye amacıyla kullanıldığını sergilemektedir. Ayrıca ordunun önüne konumlandırılmaları, yukarıda belirttiğimiz gibi düşmandan gelecek saldırıların, develerle oluşturulan siperlerle bertaraf edilmek istenmesiyle alakalıdır.

16 Kurtaran, “Osmanlı Seferlerinde Organizasyon ve Lojistik," 2281-2283.

17 Hakan Karagöz, "Petervaradin Muharebesinde (1716) Habsburgların Osmanlılardan Ele Geçirdiği Silahlar ve Teçhizat," Tarih Dergisi 59 (2008), 76; M. Yaşar Ertaş, "Osmanlı Devletinde Sefer Organizasyonu," 594.

18 Serdar Genç, "III. Ahmed Dönemi İran Seferlerinde Nakliyenin Sağlanması ve Nakliye Vasitaları (17221725)," History Studies, 4/1 (2012), 237; A. Aykut Biçer, Klasik Dönem Osmanlı Kara Ordusunda Sefer Organizesi (Ankara: Yason Yayınları, 2014), 35.

19 Emecen ve Afyoncu, Savaşın Sultanları I, 89.

20 Emecen ve Afyoncu, Savaşın Sultanları I, 23,35. 

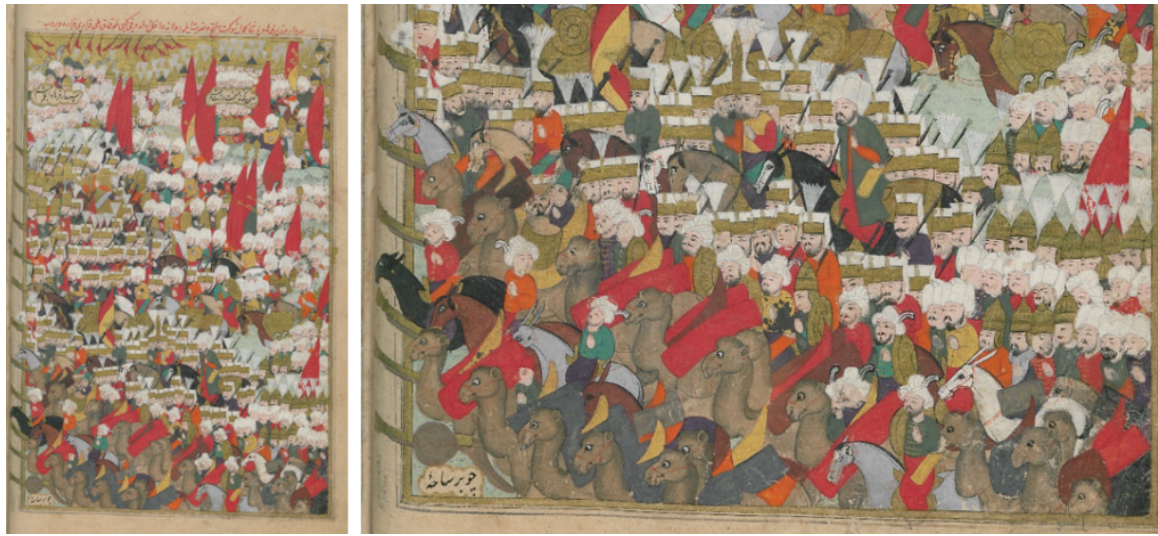

G. 2: Deve. Seyyid Lokman, Şehinşehnâme II, 1597-98, TSM, B. 200, vr.101b-102a.

Daha hafif yüklerin taşınmasında katırlardan faydalanılmıştır. Osmanlı kaynaklarında ester/esteran olarak geçen katır, deveden hızlı olması sebebiyle özellikle engebeli arazilerde ve kısa mesafelerde kullanılmıştır. Dayanıklı olması, açlığa-susuzluğa günlerce dayanması, az ses çıkarması seferlerde tercih edilme sebeplerindendir. $125-250 \mathrm{~kg}$ arasında yük taşıma kapasitesine sahip olan katır, askerlerin eşyalarının, erzağın, teçhizatın taşınmasında kullanılmıştır. ${ }^{21}$

Seyyid Lokman'1n Hünernâme II2' sinde (1579) Kanuni Sultan Süleyman'1n (15201566) Drava köprüsünden geçişi ${ }^{23}$ (G. 3) tasvir edilmiştir. Minyatürde nehirle ikiye ayrılmış arazi görülür. Merkeze Sultan konumlandırılmış ve çevresine maiyeti yerleştirilmiştir. Hepsinin dikkati ön plandaki köprüdedir. Köprü, Osiyek bölgesinin (Hırvatistan) bataklık arazi yapısı sebebiyle Sultan Süleyman'ın emriyle yapılan ve ilerleyen süreçte Avusturya ordusu tarafından yakılan Drava köprüsüdür. Ahşap malzemeli olduğu anlaşılan köprü, ikmal ve iaşenin savaş alanına ulaştırılmasında önemli rol oynamıştır. Köprüden geçmekte olan atlı birliklerinin önünde, yük taşıyan katırlar görülür. Sırtlarına bir çift sandık yüklenmiştir. Vücutlarının aldığı şekil sebebiyle zorlandıkları anlaşılan katırlar, harbendeler ${ }^{24}$ tarafından yönlendirilmektedir. Tasvir, Osmanlı’nın seferlerinde yük hayvanı olarak katır kullandığını kanıtlar niteliktedir.

21 Ersin Yıldız, “Osmanlı Devleti’nin Sefer Organizasyonlarında Kullandığı Hayvanlar (XVI.- XVIII. Yüzyıllar)," (Yüksek Lisans tezi, Ağrı İbrahim Çeçen Üniversitesi, 2019), 90-95.; S. Emir Erkmen, "Klasik Dönem Osmanlı Kara Kuvvetleri (Silahları ve Teçhizatları),” (Doktora tezi, Ankara Üniversitesi, 2019), 91.

22 Zeynep Tarım Ertuğ, "Hünernâme,” TDV Íslam Ansiklopedisi, c. 18 (İstanbul: Türkiye Diyanet Vakfı Yayınlar1, 1998), 484.

23 Sayyid Luqman, Hünernâme II, Crossing the Bridge on the Drava, from the History of Sultan Süleyman, T 413.60, Erişim 20 Eylül 2020. https://viewer.cbl.ie/viewer/object/T_413_60/2/LOG_0000/

24 Harbende, Farsçada eşek, katır gibi yük hayvanlarına bakan kişi anlamına gelir. Bk. M. Zeki Pakalın, Tarih Deyimleri ve Terimleri Sözlüğ̈̈, c. 1 (İstanbul: MEB Basımevi, 1972), 47. 


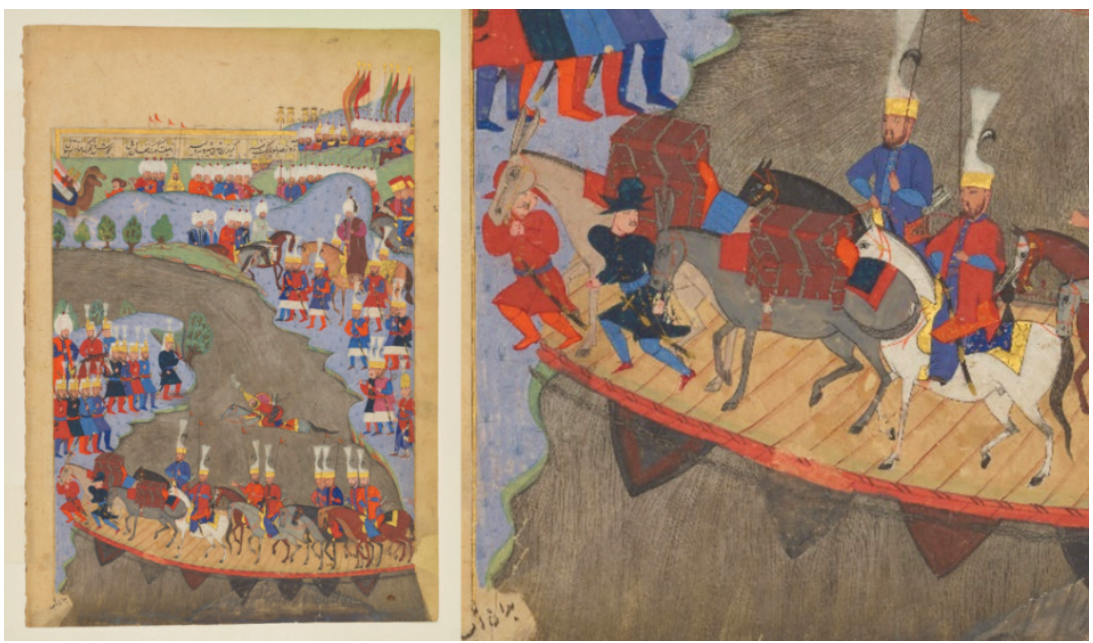

G. 3: Katır. Seyyid Lokman, Hünernâme II, H 987, CBL T 413.60v

(Chester Beatty, Dublin. CC BY-NC 4.0)

Osmanlı'nın taşıma amaçlı kullandığı hayvanlardan bir diğeri fildir. İri gövde yapısına rağmen oldukça yüksek hareket kabiliyetine sahiptir. $\mathrm{Bu}$, filin tarihin her döneminde binek ve yük hayvanı olarak kullanılmasını sağlamıştır. Çoğu İran şahlarının hediyesi olan fillerin, saray ahırlarında barındırıldığı bilinmektedir. ${ }^{25}$ Osmanlı tarihiyle ilgili kaynaklar, II. Osman'ın (1618-1622) 1621 Hotin Seferi'nde Balkanlardaki bataklık arazilerin geçilmesinde, Safevi elçisinin gönderdiği fillerden istifade ettiğini belirtmektedir. ${ }^{26}$ Bilgiyi doğrulayan minyatürlerden biri Ganîzâde Mehmed Nâdirî’nin (ö1. 1626) Şehnâme'sinde ${ }^{27}$ mevcuttur. Genç Osman'1n huzurunda ordugâhta suçluların cezalandırılması (G. 4) tasvirinde, merkezde, yüksekçe bir tepe üzerine konumlandırılmış sayebanın altındaki tahtında oturan Sultan yer alır. Sağında has odabaşı, dârüssaâde ve silahdarlar, solunda ise tımarlı sipahiler görülmektedir. Ön planda ise askerler, esirler, top arabaları ve cesetler vardır. Dikkat çeken figürlerden biri de boğumlu burnu, sivri dişleri ve küçük kulakları ile gerçekçi bir yaklaşımla ele alınan fildir. Boynunda elinde külünk tutan asker, sırtında ise ellerinde tokmak tutan közsen oturmaktadır. Duruşu itibariyle sırtında taşıdığı yüklerin ağırlığından etkilenmediği hissini uyandirmaktadır.

25 Tahsin Yazıcı, "Fil," TDV İslam Ansiklopedisi, c. 13 (İstanbul: Türkiye Diyanet Vakfı Yayınları, 1996), 67-68. 26 Kadir Kozalak ve Tufan Gündüz, “II. Osman'ın Hotin Seferi (1621),” Ankara Üniversitesi Osmanlı Tarihi Araştırma ve Uygulama Merkezi Dergisi 14 (2003), 135.

27 Mustafa İsmet Uzun, "Ganîzâde Mehmed Nâdirî," İslam Ansiklopedisi, c. 13 (İstanbul: Türkiye Diyanet Vakfi Yayınları, 1996), 355-356. 

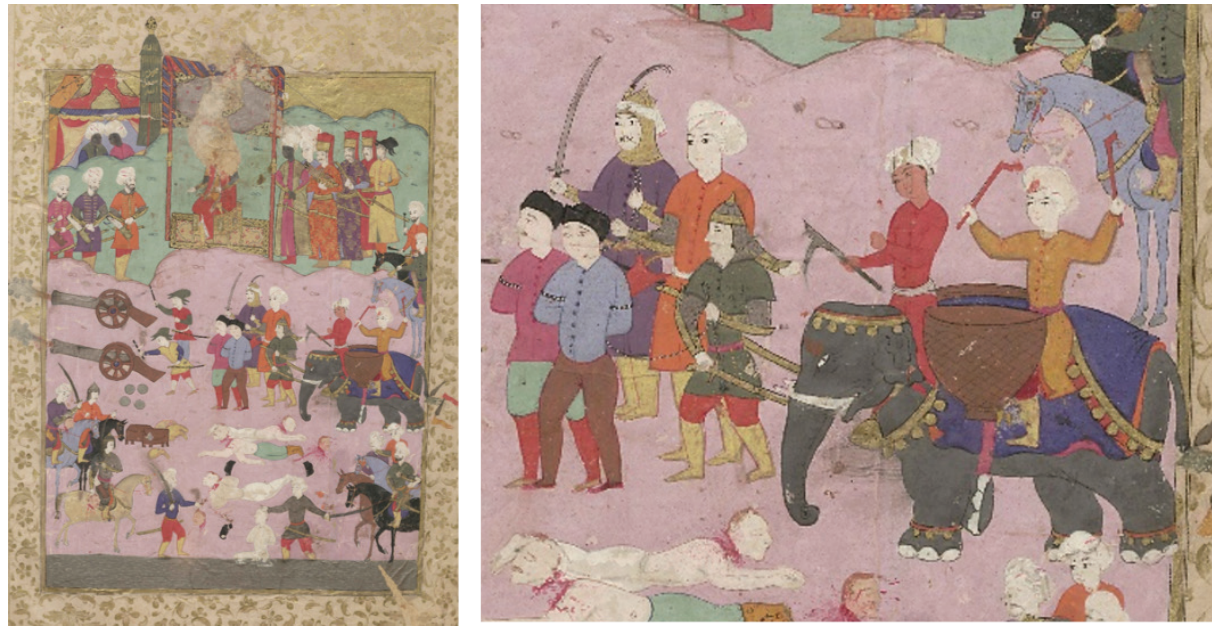

G. 4: Fil. Nadiri, Şehname, TSM, H. 1124, y.67b.

\section{Arabalar}

Erken devirlerden itibaren insan ve yük taşıma amacıyla kullanılan araçlardan biri arabadır. Tekerlekli, motorlu ya da motorsuz hareket eden taşıt olarak tanımlanır. ${ }^{28}$ Osmanlılar, seyahat amaçlı ya da cenaze, erzak ve savaş teçhizatının nakliyesinde farklı formlara sahip arabalardan istifade etmişlerdir. Günlük hayatta ve savaşta kullanılan arabalara, minyatürlerde yer verildiği görülmekle birlikte konu kapsamında, Osmanlı seferlerinde tasvir edilenler değerlendirilmiştir.

\section{a. Top arabaları}

Osmanlıların ateşli silahlar arasında yer alan topu, ilk defa kullanışına dair farklı görüşler mevcut olmakla birlikte 14. yüzyıl sonları Osmanlılar tarafından denendiği dönem olarak kabul edilmektedir. ${ }^{29}$ Top yapımı, Osmanlılar tarafından geliştirilmiş ve yine bu süreçte kullanımı yaygınlaşmıştır. Dövme ve döküm teknikleri ile yapılan toplar, kuşatmaların ve meydan savaşlarının en önemli silahı olmuştur. Tonlarca ağırlığa

28 Türkçe Sözlük 1 (Ankara: Türk Dil Kurumu Yayınları, 1998), 79.

29 Osmanlıların ilk defa top kullanımına ilişkin; Danişmend, 1386 yılında Karamanoğulları'na; Selatinname adlı eser Karahisar Fethi'ne; İlgürel 1354 Gelibolu Kuşatması'na; Çoruhlu, 1369 ilk İstanbul Kuşatması'na, Uzunçarşılı 1389 I. Kosova Kuşatması'na dikkat çekmektedir ki bu durum Neşri’nin Kitab-ı Cihan-nüma adlı eserinde de yer alır. Birçok araştırmacı ve kaynaklar, Osmanlılarda ateşli silah kullanımının başlangıcı hususunda farklı tarih ve olaylara gönderme yapsa da 14. yüzyıl, geleneksel silahların kullanım yaygınlığ beraberinde yeni teknolojilerin denenmeye başladığının habercisidir. Bk.İ. Hami Danişmend, İzahlı Osmanlı Tarihi Kronolojisi, c. 4 (İstanbul: Türkiye Yayınevi, 1947), 73;Necdet Öztürk, XV. Yüzyıl Tarihçilerinden Kemal, Selatinname (1299-1490) (İstanbul: Türk Tarih Kurumu Yayınları, 2008), 29; İ. Hakkı Uzunçarşıl1, Osmanlı Devlet Teşkilatında Kapıkulu Ocakları II (Ankara: Türk Tarih Kurumu Yayınları, 1988), 35; Mücteba İlgürel, “Osmanlı Topçuluğunun İlk Devirleri,” Prof. Dr. Hakkı Dursun Yıldız Armağanı (Ankara: Türk Tarih Kurumu Yayınları, 1995), 285-293; Mehmet Neşri, Kitâb-ı Cihan-Nüma Neşrî Tarihi II, haz. F. R. Unat ve A. Köymen (Ankara: Türk Tarih Kurumu Yayınları, 1987), 565-667; Tülin Çoruhlu, Osmanlı Tüfek, Tabanca ve Teçizatları (Askerî Müzeden Örnekler) (Ankara: Genelkurmay Basımevi, 1993), 2. 
sahip olan topların, savaş alanına sevk edilmesi gerekliliği bunları taşıyacak arabaların yapılmasını zaruri kılmıştır. Önceleri topçu ocağına bağlı görevliler tarafından yapılan arabalar, 15. yüzyılın 2. yarısından itibaren top arabacıları ocağında üretilmiştir. ${ }^{30}$

Günümüzde çeşitli müzelerde sergilenen top arabaları, Osmanlı dönemi sefer konulu minyatürlerinde de işlenmiştir. Hücum ve kuşatma sahnelerinde görülen arabalar, iki tekerlekli olup kuyruklu ya da kuyruksuz olarak tasvir edilmişlerdir. Kısa ya da uzun namlulu topların yüklendiği arabalar, ya savaş alanında dağınık hâlde gösterilmiş ya da bir metrisin arkasında yer almıştır. ${ }^{31}$

Ârifi Fethullah Çelebi'nin (öl. 1561) Süleymannâme'sindeki ${ }^{32}$ Mohaç Savaşı (G. 5) minyatürü, savaş ortamını yansıtmasının yanı sıra Osmanlı'nın savaş düzeni ve kullandığ1 teçhizatları yansıtması açısından önemlidir. Her biri dilimli ispitlere sahip tekerlerin, dingille birleştirilmesiyle vücut bulan arabaların üstünde, kundağa yerleştirilmiş kısa namlulu toplar görülür. Burada önemli olan bir diğer husus ise arabaların birbirlerine zincirlerle tutturulmasıdır. Ordu merkezinde savunma hattı (tabur cengi) oluşturulmasında, zincirlerle bağlanan arabalardan istifade edildiği bilinmektedir. ${ }^{33}$
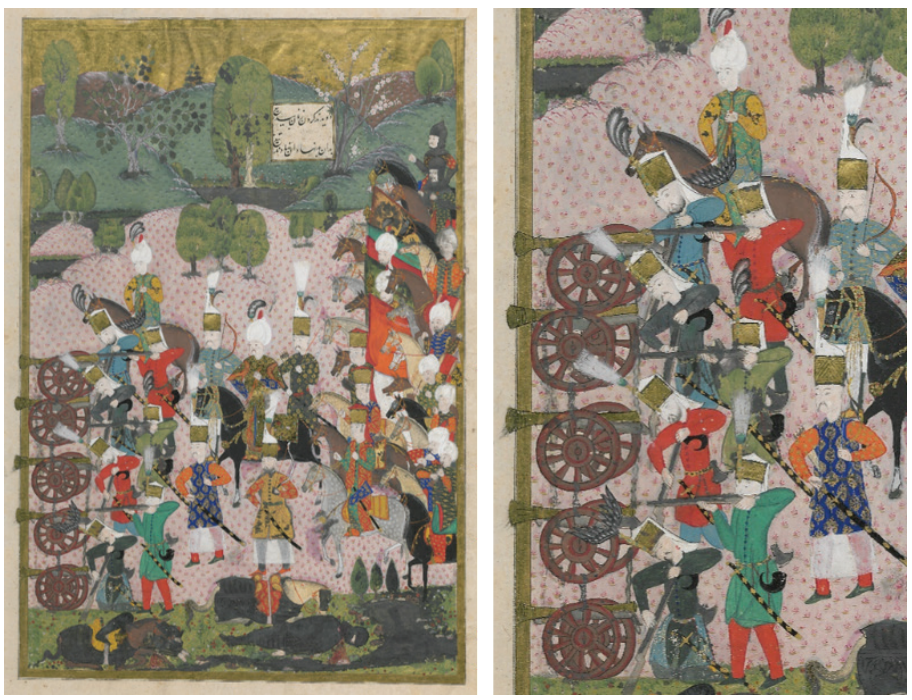

G. 5: Zincirle bağlanmış top arabaları. Arifi, Süleymannâme. TSM, H.1517 y.219b.

30 Gabor Agoston, “Top,” TDV İslam Ansiklopedisi, c. 41 (İstanbul: Türkiye Diyanet Vakfı Yayınları, 2012), 240.

31 Dilek Doğan, 16.-18. Yüzyıl Minyatürlerinde Osmanlı Arabaları (Yüksek Lisans tezi, Marmara Üniversitesi, 2011), 324.

32 Abdurrahman Sağırlı, "Süleymannâme,” TDV İslam Ansiklopedisi, c. 38 (İstanbul: Türkiye Diyanet Vakfı Yayınlar1, 2010), 126.

33 Gabor Agoston, Osmanlı'da Savaş ve Serhad, çev. K. Şakul (İstanbul: Timaş Yayınları, 2013), 86. 
Farklı bir top arabası tasviri, Seyyid Lokman'ın Hünernâme I (1579-85) eserinde, Macarların Niğbolu Kalesini Muhasarası (G. 6) sahnesinde yer almaktadır. Niğbolu Savaşı, Türklerin Balkanlar'daki ilerleyişini durdurmak amacıyla gerçekleştirilen son haçlı seferidir ve Tuna nehri kıyısında sarp bir mevkide yer alan Niğbolu kalesinin önünde gerçekleşmiştir. İstanbul muhasarası sırasında Haçlı ilerleyişini haber alan Yıldırım Bayezid (1389-1403), ordusuyla birlikte Niğbolu'ya hareket etmiş ve uygulamış olduğu savaş taktiğiyle haçlıları mağlup etmiştir. ${ }^{34}$ Minyatürde sahne, nehirle (Tuna) ikiye ayrılmıştır. Solda, kayalıklar üzerinde kaynaklarda da belirtildiği gibi Niğbolu Kalesi görülmektedir. Kalenin hemen solunda dikkati üzerinde toplayan Y1ldırım Bayezid yer alır ki bu da kuşatma haberini alır almaz, bölgeye intikal etmesini ifade etmektedir. Top arabaları sağdaki metrislerin arkasındadır. Dilimli ispitlere sahip tekerlerin dingil vasıtasıyla birleştirilmesiyle yapılan arabaların üzerinde, kundağa yerleştirilmiş uzun namlulu toplar bulunmaktadır. Bu araba, tekerlekli bir kuyruğa sahip olması yönüyle önceki tasvirdekinden farklıdır.
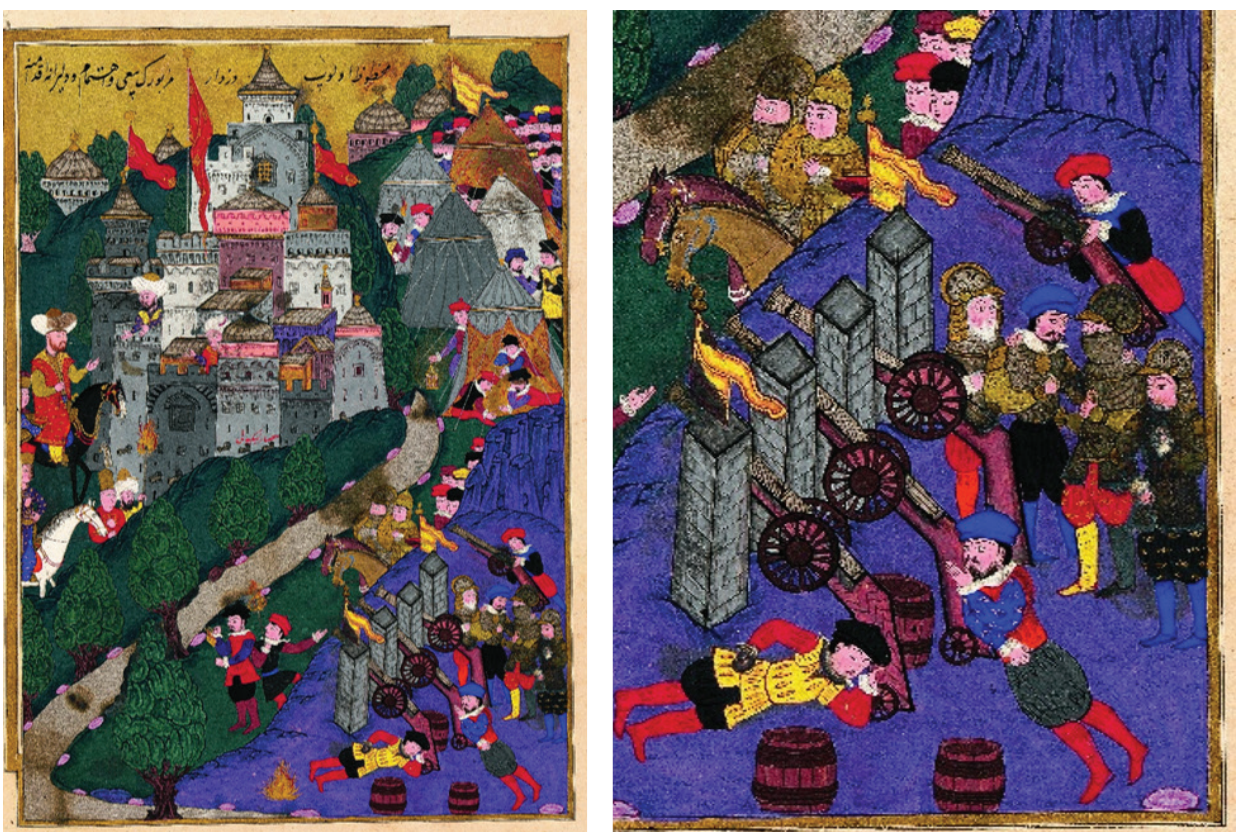

G. 6: Kuyruklu top arabalar1. Seyyid Lokman, Hünernâme I. TSM, H.1523, y.108b.

34 Feridun Emecen, "Niğbolu Savaşı," TDV Íslam Ansiklopedisi, c. 33 (İstanbul: Türkiye Diyanet Vakfı Yayınlar1, 2007), 89-92. 


\section{b. Saltanat-Cenaze Arabalari ${ }^{35}$}

Osmanlı Devleti saray mensupları ve askeri zümresi, sefer sırasında vasıta olarak at kullanmış, rehavete düşürmesi sebebiyle arabadan uzak durmuştur. ${ }^{36}$ Bununla birlikte hasta ve yaralıların nakli, yanı sıra cenaze taşıma gibi bazı özel durumlarda seferlerde arabalardan istifade edildiğ $\mathrm{i}^{37}$ hem kaynaklardaki bilgilerden hem de yazma eserlerdeki minyatürlerden anlaşılmaktadır. Tasvirlerde izlenen sefer arabaları, tekerlekli ve tekerleksiz olmak üzere iki sınıfa ayrılır.

Seyyid Lokman tarafindan yazılan Tarih-i Sultan Süleyman (1579) ${ }^{38}$ adlı eserde saltanat/cenaze arabası tasviri görülür. Kanuni Sultan Süleyman’1n, hastalığı ve yaşl1lığ1 sebebiyle Zigetvar Seferi’ne arabayla katılmak zorunda kaldığ 1 , hatta zaferden kısa bir süre önce vefat edince, orduda zafiyet oluşmaması adına durumun gizlendiği ve dönüş yolunda kendisine benzer birinin üstü kapalı arabaya yerleştirilerek, askeri selamladığ 1 belirtilmektedir. ${ }^{39}$ Bunun yanı sıra durumun kırk günden fazla saklandığ 1 ve cenazenin Sigetvar'da kurulan Otağ-1 Hümayun'da muhafaza edildiği, şehzade Selim'in Belgrad'a yaklaşması üzerine kefenlenerek padişah sağmış gibi arabaya konmasının ardından yola çıkıldığı da kaynaklarda yer alan bilgilerdendir. ${ }^{40}$ Tarih- $i$ Sultan Süleyman'da tasvir edilen Osmanlı ordusunun Belgrad'a dönüşü (G. 7) isimli minyatür bu anlatımları desteklemektedir. Geniş açılı tasvirde, disiplinli bir şekilde ilerleyen Osmanlı ordusu görülmektedir. Sağ sayfada minyatürün merkezine konumlandırılmış araba dikkat çekmektedir. Hanto/hinto ${ }^{41}$ olarak isimlendirilen arabanın iki at tarafından çekildiği gözlenmektedir. Gövdesi dilimli tekerlere oturtulan arabanın üstü mavi astarlı kırmızı bir örtü ile kapatılmıştır. Örtünün uç kısımları simetrik şekilde iki kenara çekilmiş ve tam ortasına, Sultan'ı simgelemesi amacıyla bir kavuk yerleştirilmiştir. ${ }^{42}$

35 Kanuni Sultan Süleyman'ın Zigetvar kuşatmasına karar verildiği zaman yetmiş yaşın üzerinde ve hasta olması sebebiyle -uzun sürecek sefer yolculuğunda daha az yorulması adına- saraydan arabayla ayrıldığı bilinmektedir. Ele alınan araba tasviri Parladır ve Tarım Ertuğ tarafından cenaze arabası; Börekçi tarafından ise kraliyet arabası olarak tanımlanmaktadır. Kanuni'nin sefer sırasında vefat etmesi üzerine aynı vasıtanın cenazeyi taşımak için de kullanılması dolayısıyla arabanın her iki ifadeyi de karşıladığı düşünülebilir. Detaylı bilgi için bk. Günhan Börekçi, "The Memory of Szigetvárand Sultan Süleyman in Ottoman/TurkishCulture," The Battle for Central Europe, ed. Pál Fodor, Leiden: Brill Pub., 2019, 523. Tarım Ertuğ, "The Depiction of Ceremonies In Ottoman Miniatures: HistoricalRecordor a Matter Of Protocol," 265; Parladır, "Sigetvar Seferi Tarihi ve Nakkaş Osman," 75.

36 Vahdettin Engin, "Otomobil Öncesinde İstanbul'da Kara Ulaşımı," Osmanlı İstanbulunda Otomobil, ed. Erhan Afyoncu ve Coşkun Yılmaz (İstanbul: Türkiye Turing ve Otomobil Kurumu, ty.), 61.

37 Mehmet İpşirli, “Araba,” TDV İslam Ansiklopedisi, c. 3 (İstanbul: Türkiye Diyanet Vakfı Yayınları, 1991), 243.

38 Sayyid Luqman, "Süleyman's Body Escorted Back to Istanbul by the Ottoman Army, from the History of Sultan Süleyman", History of Sultan Süleyman, https://viewer.cbl.ie/viewer/image/T_413_113/2

39 İpşirli, “Araba,” 243.

40 Zeynep Tarım Ertuğ, “Osmanlı Devleti’nde XVI. Yüzyıl Cülus ve Cenaze Törenleri” (Doktora tezi, İstanbul Üniversitesi, 1995), 105.

41 Doğan, “16.-18. Yüzyıl Minyatürlerinde Osmanlı Arabaları,” 68.

42 Detaylı bilgi için bk. Tarım Ertuğ, "Cülus ve Cenaze Törenleri,” 128. 

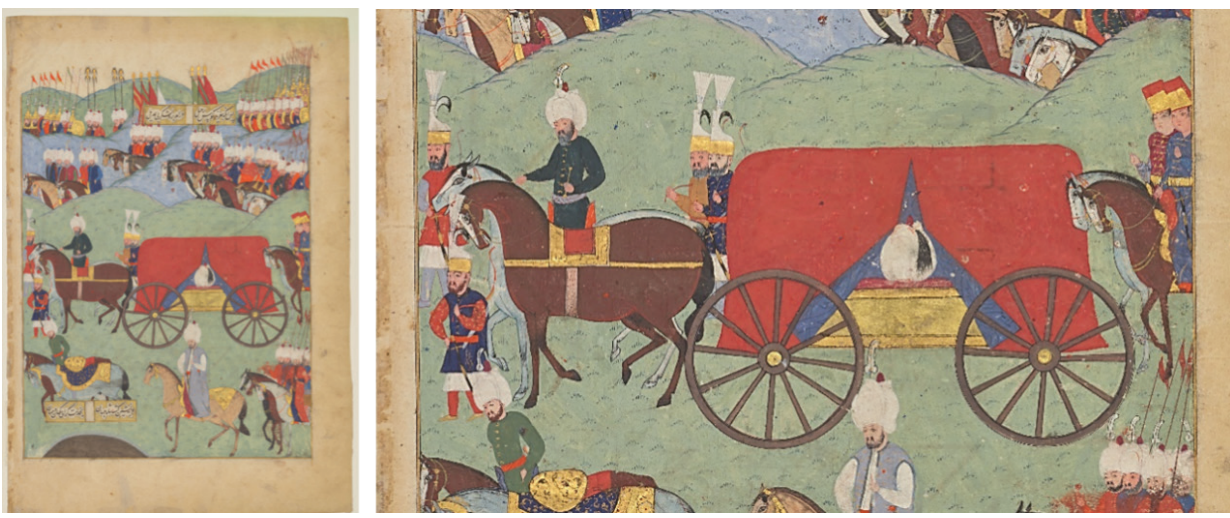

G. 7: Saltanat/Cenaze arabası. Seyyid Lokman, Tarih-i Sultan Süleyman, 1579 T.413.113.v

(Chester Beatty, Dublin. CC BY-NC 4.0)

Osmanlı seferleriyle ilgili minyatürlerdeki bir başka taşıma aracıda tahtırevandır. Tahtırevan, "İnsan omzunda veya deve, fil, at gibi hayvanlara yüklenerek götürülen, üstü örtülü tekerleksiz taşıt" ${ }^{` 43}$ olarak tanımlanmaktadır. Özdemiroğlu Osman Paşa dönemi olaylarını anlatan, Dal Mehmed Çelebi (Âsafî)'nin Şecaâtnâme'sinde ${ }^{44}(1586)$ tahtırevan tasviri mevcuttur. Safevilerin, Kafkasya'daki ilerleyişini durduran Osman Paşa, III. Murad (1574-1595) tarafından veziriazamlığa atanmış ve ardından İran seferine katılmıştır. Bu sefer sırasında rahatsızlanınca, tahtırevanda taşınarak bölgeye ulaştırılmıştır. ${ }^{45}$ Osman Paşa öldüğü hâlde, yeniçerinin morali bozulmasın diye ölüsü canlıymış gibi geçiriliyor ${ }^{46}($ G. 8) isimli tasvirde, tepeler arasında Osmanlı ordusu ve esirler görülmektedir. Kompozisyonun ana unsuru olan tahtırevan, ön plandadır. Yeniçerilerin refakat ettiği Osman Paşa, harbende tarafından yönlendirilen, sırtlarında süslü örtüler bulunan develere yüklenmiş baldaken formlu, kubbeli ve perdelerle taçlandırılmış tahtırevanda yastığa dayanmış ve üstü nakışlı örtüyle kapatılmış bir şekilde gösterilmiştir. Tasvir, taşımacılıkta tahtırevandan da istifade edildiğini yans1tan örneklerden biridir.

43 Türkçe Sözlük II (Ankara: Türk Dil Yayınları, 1988), 1403.

44 Şecâatnâme hakkında detaylı bilgi için bkz. Süleyman Eroğlu, "Âsafî’nin Şecâat-Nâme Mesnevisi," Turkish Studies International Periodical For the Languages, Literature and History of Turkish or Turkic, 4/7 (2009) DOI:http://dx.doi.org/10.7827/TurkishStudies.908; Zehra Göre, “Âsafî Dal Mehmed Çelebi'nin Şecâ'atNâme'sinde Edebî Tasvirler,” Osmanlı Mirası Araştırmaları Dergisi 6/16 (2019), 401-431.

45 Kemal Çiçek, “Osman Paşa, Özdemiroğlu,” TDV İslam Ansiklopedisi, c. 33 (İstanbul: Türkiye Diyanet Vakfı Yayınlar1, 2007), 472.

46 Serpil Bağcı vd., Osmanlı Resim Sanatı, 169. 

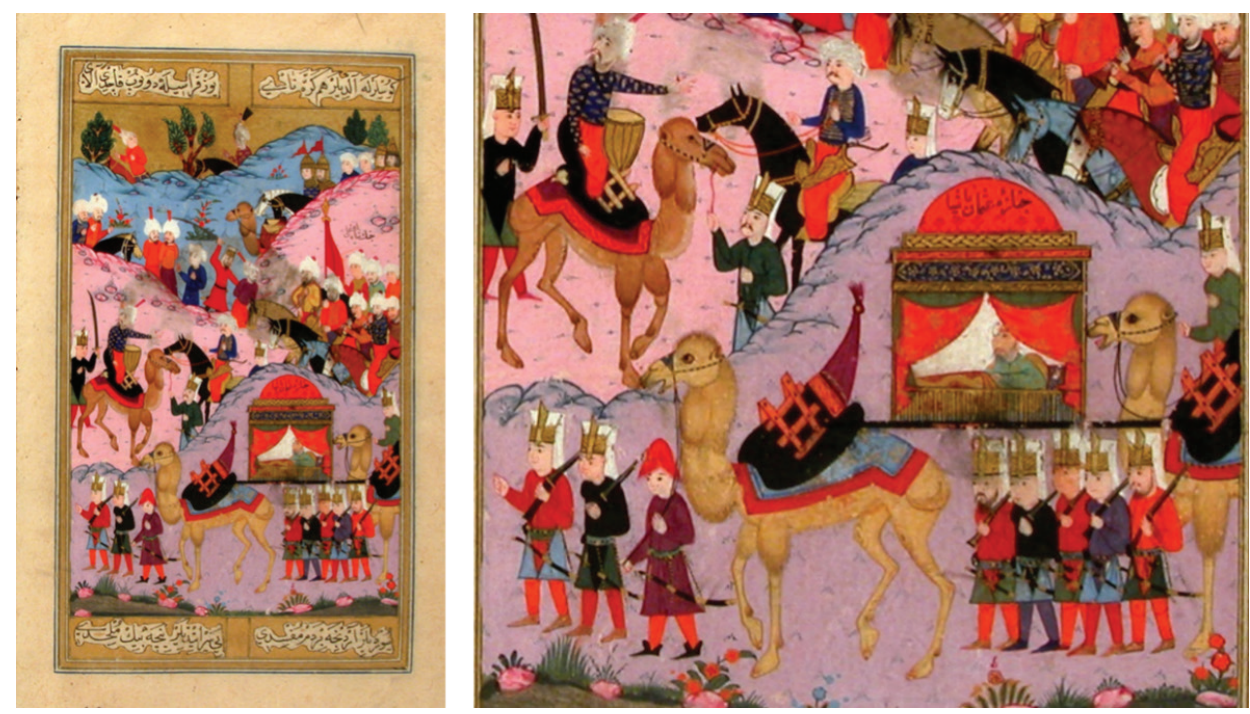

G. 8: Tahtırevan. Âsafi, Şecâatnâme. İÜK. T6043/281b

\section{Deniz Taşımacılığında Kullanılan Sefer Vasıtaları}

Gaza faaliyetlerini, denizyolundan da sürdürmek isteyen Osmanlılar, Batı Anadolu'daki Aydınoğulları, Saruhanoğulları, Menteşeoğulları ve Karesioğulları gibi beyliklerin donanmalarını temel alarak bir donanma oluşturmuştur. Özellikle Karesi Beyliği'nin alınmasıyla sınırları denizlere ulaşan Osmanlı'nın, egemenlik sahasını genişletme arzusu deniz yoluyla gerçekleştirilecek fetihlerde donanmanın önemini fark etmesini sağlamış ve Edincik, Karamürsel, İzmit gibi merkezlerde tersaneler inşa edilmiştir. Balkanlar'a gerçekleştirilecek fetihler, Marmara ile Karadeniz'e geçişin elde tutulması ve Anadolu-Rumeli arasındaki bağlantıyı sağlamak amaciyla Gelibolu fethedilmiş, tersane kurularak deniz üssü hâline getirilmiştir. İstanbul'un fethinde kullanılacak gemilerin tamiri ve yenilerinin inşası burada gerçekleştirilmiştir. ${ }^{47}$

Erken dönemde akın donanması şeklinde faaliyet gösteren Osmanlı, önemli bir jeopolitik konumda bulunan İstanbul'un fethi ile açık denizlere yönelme isteği duymuş ve imparatorluk donanması oluşturulması yönünde girişimlere başlanmıştır. Fatih Sultan Mehmed'in (1444-1446, 1451-1481) kurduğu, Yavuz Sultan Selim'in (1512-1520) asıl şeklini verdiği Galata Tersanesi (Tersane-i Amire) ve diğerlerinde ${ }^{48}$ kaynaklarda kürekli (çektiri), yelkenli ve buharlı ana başlıkları altında ele alınan sefer vasıtalar. ${ }^{49}$ inşa edilmiştir. Savaşın gerçekleşeceği alan gemi taşımacılığına uygun bir konumda

47 İdris Bostan, Beylikten Imparatorluğa Osmanlı Denizciliği (İstanbul: Kitap Yayınevi, 2007), 13-15.

48 İdris Bostan, “Tersane-i Amire,” TDV İslam Ansiklopedisi, c. 40 (İstanbul: Türkiye Diyanet Vakfı Yayınları, 2011), 513; Püryani Fidannaz, "İmparatorluğa Geçiş Sürecinde Osmanlı Denizciliği," Uluslararası Sosyal Araştırmalar Dergisi 50 (2017), 217; Bostan, Beylikten İmparatorluğa Osmanlı Denizciliği, 13.

49 İdris Bostan, “Gemi,” TDV İslam Ansiklopedisi, c. 14 (İstanbul: Türkiye Diyanet Vakfı Yayınları, 1996$), 11$. 
ise sefer teçhizatı ve iaşenin nakli karayoluna göre daha ucuz ve kolay olan denizyolundan sağlanmıştır. ${ }^{50}$

Osmanlı donanmasını oluşturan ve seferlerde kullanılan gemilerin, dönem yaşantısına 1şık tutan el yazmalarındaki minyatürlerde işlendiği görülmektedir. Ele almış olduğumuz 16.-18. yüzyıla tarihlendirilen minyatürlerde, Osmanlı gemilerini kürekli ve yelkenli olmak üzere iki başlık altında değerlendirmek mümkündür.

\section{a. Kürekli gemiler}

Çektiri olarak da adlandırılan bu gemiler, kürek ve kısmen yelkenle hareket etmektedir. Büyüklükleri ve formları farklılık göstermekle birlikte, oturak sayılarına ${ }^{51}$ göre kadırga, baştarda, mavna, kalyata, fırkate... gibi "büyük donanma gemileri” ve Karamürsel, şayka, aktarma... vs. yer aldığı "ince donanma gemileri” olmak üzere ikiye ayrilırlar. ${ }^{52}$

Kürekli gemilerin başlıca temsilcisi kadırgadır. Kuruluştan 17. yüzyıl sonlarına kadar donanmada yer almıştır. ${ }^{53}$ Dar, borda yüksekliği az, baş kısmında çıkıntısı olan kadırgalar ticaret ve savaş gemisi olarak kullanılmıştır. Uzunluğu ölçüsünde hareket etme kabiliyetine sahip ${ }^{54}$ olan bu gemi yelken yardımc1lı olmakla birlikte rüzgârsız havalarda ya da liman giriş-çıkışlarında küreklerle hareket ettirilirdi. ${ }^{55}$

Matrakçı Nasuh (öl. 1564)'a atfedilen Târîh-i Feth-i Şikloş, Estergon ve Istolni Belgrad (1543) ${ }^{56}$ eserinde yer alan Toulon şehri minyatüründe kadırgalar mevcuttur (G. 9). Kanuni Sultan Süleyman, Şarlken üzerine gerçekleştirmeyi düşündüğü sefer için Barbaros'u Tersane-i Âmire'nin başına geçirmiş ve aralarında kadırgaların da olduğu bir donanma hazırlatmıştır. ${ }^{57}$ Tunus seferine çıkan donanma, öncelikle İtalya kıyılarında yer alan şehirleri zapt etmiştir. ${ }^{58} \mathrm{Açık} \mathrm{kompozisyon} \mathrm{şemasındaki} \mathrm{Toulon}$ minyatüründe, arka planda şehir ve tepeler, ön planda ise çizgisel üsluptaki kadırgalar görülmektedir. İnce, uzun, bordaları alçak formlu gemiler, küreklidir. Kıç kısımları, baş taraflarından yüksek tasarlanmış ve önlerine mahmuz eklenmiştir ve kadırga ta-

50 Ertaş, Osmanlı Devletinde Sefer Organizasyonu, 594-595.

51 Kâtip Çelebi, Tuhfetüıl-Kibâr fì Esfâri’l-bihar, çev. İdris Bostan (Ankara: TÜBA Yayınları, 2018), 231 - 251.

52 İdris Bostan, "Gemi," 11-13.

53 İdris Bostan “Gemi,”12.

54 Kâtip Çelebi, Tuhfetü>l-Kibâr fì Esfâri’l-bihar, 232.

55 Aydın, "Osmanlı Denizciliği (1700-1770)," 5-6; Bostan, "Gemi," 13; İdris Bostan, "Kadırga'dan Kalyon'a", The Journal of Ottoman Studies XXIV (2004), 65-67.

56 Detaylı bilgi için bk. Sinan Çavuş, Süleymanname Tarih-i Feth-i Şikloş Estergon ve Istol(n)i Belgrad (İstanbul: TAD Merkezi Kurma ve Geliştirme Vakfı Yayınları, 1998).

57 Haluk Y. Şahsuvaroğlu, "Barbaros’un Seferleri,” Tarihten Sayfalar, Taha Toros Arşivi. https://core.ac.uk/ download/pdf/38326634.pdf, erişim tarihi: 12 Aralık 2020

58 Hüseyin Gazi Yurdaydın, "Matrakçı Nasuh,” TDV İslam Ansiklopedisi, c. 28 (Ankara: Türkiye Diyanet Vakfı Yayınları, 2003), 143; Mahir, Osmanlı Minyatür Sanatı, 55. 
nımlarıyla uyuşmaktadır.
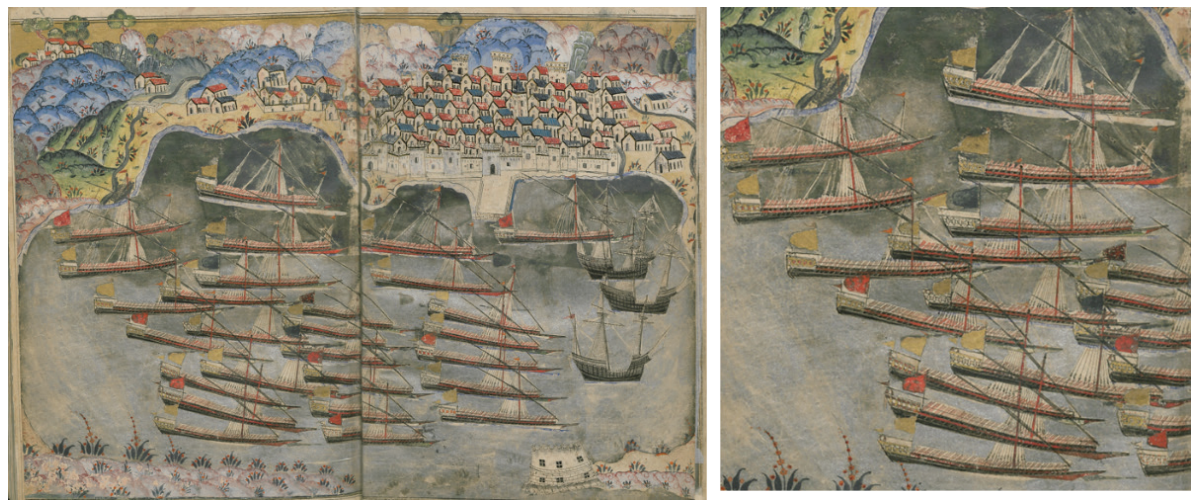

G. 9: Kadırgalar. Nadiri, Şehnâme. TSM, H.1124, 22b-23a.

Çektiri sınıfındaki bir diğer gemi baştardadır. 16. yüzyılda donanmaya katılmıştır. Kadırgadan büyük olup tersane kethüdası, tersane emini ve kaptan paşa tarafından kullanılmıştır.26 oturaklı olanı "ortalık", 36 oturaklısı "paşa” ve direkleri, kürekleri, bayrağı yeşil, üç fenerli olanı ise "hünkâr" olarak isimlendirilir. ${ }^{59}$ Ganîzâde Nâdirî'nin (öl. 1627) Şehnâme’sinde, Kaptan-1 Derya Ali Paşa’nın, düşman ile gerçekleştirdiği deniz savaşını anlatan minyatürde baştardaya yer verilmiştir (G. 10). Güzelce Paşa'nın, zaferle sonuçlanan deniz savaşının ardından ele geçirdiği gemileri, II. Osman'a (1618-1622) sunduğu ve bunun sonucunda sadrazamlığa atandığı bilinmektedir. ${ }^{60}$ Savaşı anını yansıtan tasvirde farklı formlarda gemilerle birlikte baştarda da görülür. Dar ve uzun formlu baştardanın, kadırgadan gösterişli bir tasarıma sahip olduğunu söylemek mümkündür. Kıç (pupa) kısmı, baş tarafına göre oldukça yüksek tasarlanmış olup geceleri yakılan üç fenerle taçlandırılmıştır. Bu durum paşa baştardası olduğunu sergilemektedir.

59 Kâtip Çelebi, Tuhfetǜl-Kibâr fi Esfâri'l-Bihâr, 232.

60 Şerife Akpınar, "Minyatürlerle Süslenmiş Manzum Bir Tarih: Şeh-nâme-i Nâdirî," Divan Edebiyatı Araştırmalart Dergisi 23 (2019), 18. 

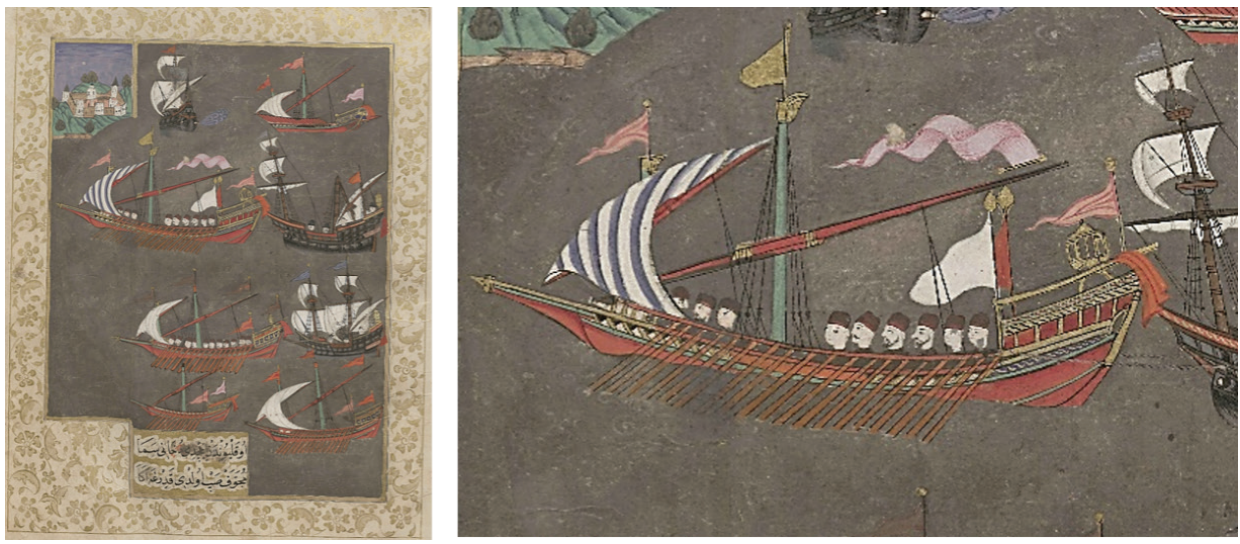

G. 10: Paşa Baştardası. Nadiri, Şehname. TSM, H.1124, y.29a.

Bu grupta yer alan bir diğer gemi türü mavnadır. Baştardadan yüksek, geniş fakat kısadır. 15.-18. yüzyıllarda donanmada yer almıştır. İki katlı tasarlanan mavna, yaygın kullanılan savaş gemilerindendir. ${ }^{61}$ Mavnanın tasvir edildiği yazmalardan biri, Kâtip Çelebi'nin (öl. 1657) Tuhfetü'l-Kibâr fî Esfâri’l-Bihâr'ıdır (G. 11). Osmanlı İmparatorluğu'nun deniz tarihi ve denizcilik organizasyonlar1 ${ }^{62}$ bilgiler veren bu çalışmada yer alan mavnanın iki katlı ve oldukça gösterişli olduğu görülür.

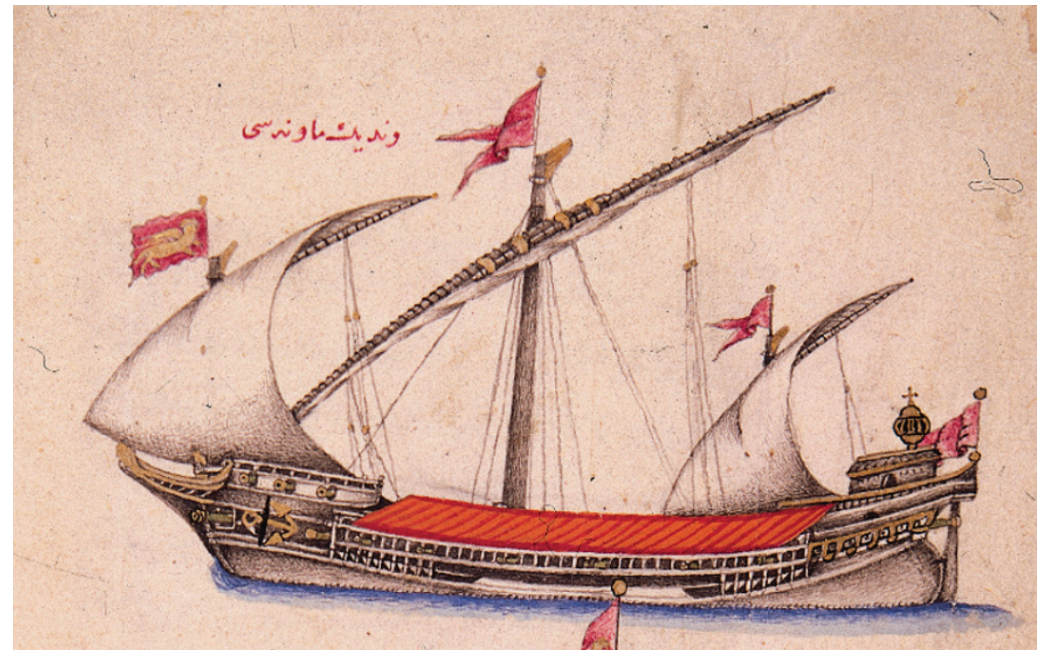

G. 11: Mavna. Kâtip Çelebi, Tuhfetü'l-Kibâr fì Esfâri'l-Bihâr. TSM, H. 1192, y.16b.

61 İbrahim Hakkı Uzunçarşılı, Osmanlı Devletinin Merkez ve Bahriye Teşkilatı (Ankara: Türk Tarih Kurumu, 1988), 459-462; Mustafa Çırpan, “Osmanlı Devleti’nde Gemi Tipleri ve Gemi Kazaları ile İlgili Değerlendirmeler," Gemi Inşaatı ve Deniz Bilimleri Dergisi 19 (2020), 46.

62 Kâtip Çelebi, Tuhfetü)l-Kibâr fì Esfâri'l-Bihâr, 99. 
İnce donanma gemileri sınıfında kancabaşlar da vardır. Ön tarafının kancaya benzetilmesi dolayısıyla bu ismi almıştır. Asker, tahıl ve mühimmat taşımacılığında kullanılan kancabaş, nehir ve sığ sahillerde tercih edilmiştir. ${ }^{63}$ Osmanlı ve Ruslar arasında Karadeniz'de gerçekleşen savaşları içeren Keyfìyet-i Rûsiye ${ }^{64}$ isimli eserde yer alan minyatürde, tanıma uyan kancabaş tasviri yer alır (G. 16).

\section{b. Yelkenli gemiler}

Tamamen yelken desteğiyle hareket eden gemiler,15. yüzyıl sonunda inşa edilmiş ancak yaygınlaşmamıştır. ${ }^{65}$ 16. yüzyıl sonunda Avrupalı devletlerin bunları savaş gemisine dönüştürmesi ve etkin bir şekilde kullanması, Osmanlı donanmasının çektiri sınıfından yelkenli gemilere geçişini zorunlu kılmıştır. ${ }^{66} 17$. yüzyıl sonu ile 18. yüzyıl başında, denizlerdeki hâkimiyetin korunması için donanmada yeni bir yapılanmaya gidilmiş, yelkenli gemilere yönelme gerçekleşmiş ${ }^{67}$ ve 19. yüzyıl ortalarına kadar kullanılmıştır. ${ }^{68}$ Yelkenle hareket eden gemiler için kalyon terimi kullanılmakla birlikte direk sayılarının, biçimlerinin ve ebatlarının çeşitlilik göstermesi farklı isimlerle anılmalarını sağlamıştır.

Osmanlılarda üç direkli ve üç ambarlı olan en büyük yelkenlilere kalyon denilmiştir. 16. yüzyıl başından 17. yüzyıl ortalarına kadar, donanma gücü olmasından ziyade nakliye amaçlı kullanılmıştır. Seferlerde ilk kullanılışına ait bilgiler sınırlı olsa da II. Bayezid döneminde donanmaya katıldığı ancak 17. yüzyıl sonuna kadar yaygınlaşmadığı anlaşılmaktadır. Osmanlılar, kalyon için "göke/küke" tabirini kullanmıştır. ${ }^{69}$ Kâtip Çelebi Tuhfetü'l kibâr fi esfâri'l-bihar adlı eserinde göke için "altı mavna üstü kalyon" şeklindedir gibi bir tanımlama yapmış ve eklediği minyatürle de (G. 12) bunu desteklemiştir. Baş kasaranın, kıça göre alçak tasarlanması ve pruvada baş figürüne yer verilmesi yönüyle kalyon formunu yansıtsa da kadırgalarda görülen mahmuz ve kürekleri eklemesi ifadesini güçlendirmektedir. Kâtip Çelebi'nin hayal dünyasında kurguladığ 1 kalyonu tasvir ettiği kabul edilmektedir. ${ }^{70}$

63 Bostan, "Gemi," 14.

64 Metin And, Osmanlı Tasvir Sanatlarl I: Minyatür (İstanbul: Yapı Kredi Yayınları, 2014), 365.

65 Y. Alperen Aydın, “Osmanlı Denizciliği (1700-1770),” (Doktora tezi, İstanbul Üniversitesi, 2007$), 11$.

66 Aydın, “Osmanlı Denizciliği,” 8; Bostan, Beylikten Imparatorluğa Osmanlı Denizciliği, 184-188.

67 Aydın, “Osmanlı Denizciliği,” 20; Nejat Tarakçı, Deniz Gücünün Osmanlı Tarihi Üzerindeki Etkileri (İstan-

bul: Deniz Basımevi, 2009), 268.

68 Bostan, Beylikten İmparatorluğa Osmanlı Denizciliği, 184.

69 Aydın, "Osmanlı Denizciliği," 83.

70 Aydın, “Osmanlı Denizciliği, ” 40. 


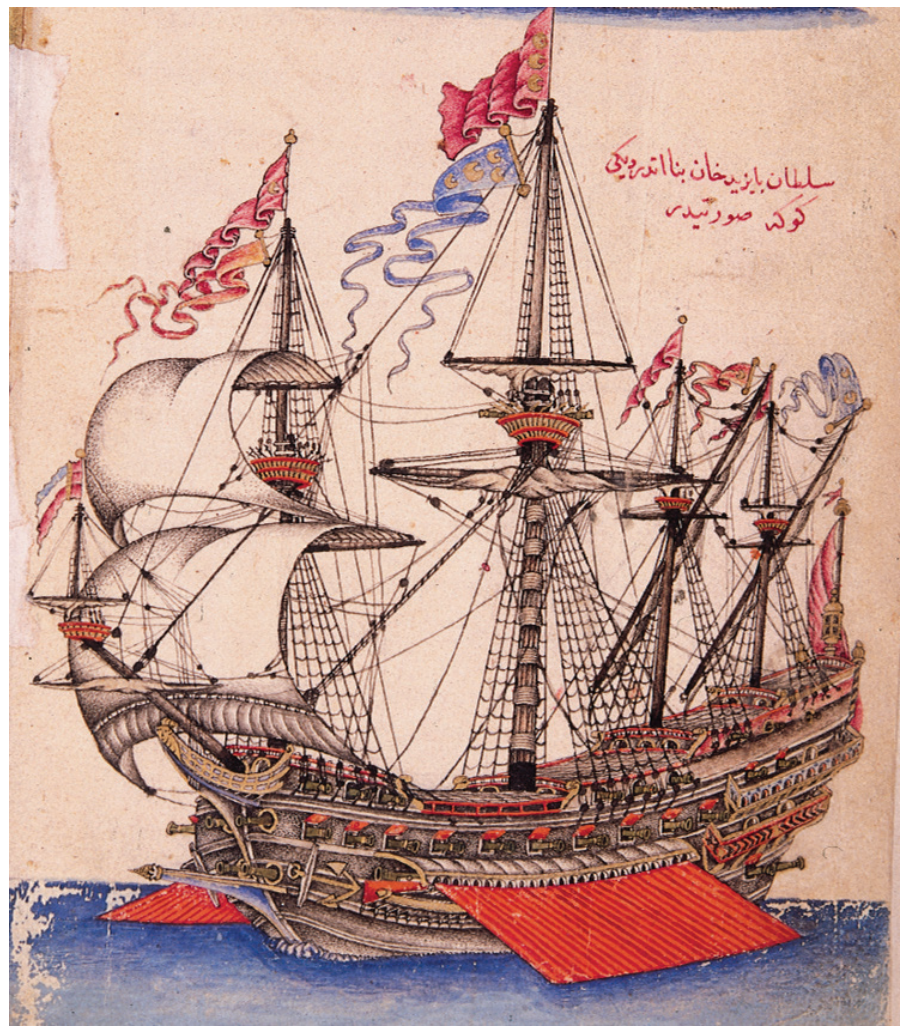

G. 12: Göke/Küke. Kâtip Çelebi, Tuhfetü'l-Kibâr fì Esfâri'l-Bihâr. TSM, H.1192

Barça, Osmanlı donanmasındaki gemilerinden bir diğeridir. Altı düz, iki ya da üç direklidir. Ticaret ve savaş amaçlı kullanılmıştır. ${ }^{71}$ Barça tasvirlerinden biri, Seyyid Lokman'in Hünernâmel'inde ${ }^{72}$ mevcuttur. Fatih Sultan Mehmed'in Belgrad Kalesi'ne saldırma anını yansıtan minyatürün (G. 13) merkezinde, şahlanmış atının üstünde düşmanı k1lıçtan geçirir şekilde betimlenen Sultan yer almaktadır ve gemi tasviri hemen onun arkasındadır. Belgrad'ın, Tuna ve Sava nehirlerinin birleşme noktasında ve etrafı su dolu hendeklerle çevrili muhkem bir kaleyle korunuyor olması hem karadan hem denizden kuşatılmasını gerekli kılmıştır. Kaynaklarda, donanmanın, kalyon ve kadırgaların oluşturulduğu bilgisi mevcuttur. ${ }^{73}$ Betimlenen geminin tek yelkenli ve küreksiz olması, bunun kalyon sınıfinda değerlendirilen barça olduğunu ortaya koymaktadır. Barçanın Fatih Sultan Mehmed'in İstanbul'un fethinde uyguladığı gemileri karadan yürütme taktiğini, Belgrad kuşatmasında da gerçekleştirdiği sembolizmini de taşıdığ 1 düşünülebilir.

71 Bostan, “Gemi," 14.

72 Nigar Anafarta, Hünernâme Minyatürleri ve Sanatçıları (İstanbul: Doğan Kardeş Matbaacılık, 1969), 29.

73 İlhan Türkmen, "Fatih Sultan Mehmed Dönemi Sirbistan Seferleri," Asia Minor Studies 3/5 (Ocak 2015), 115-134, https://dergipark.org.tr/tr/pub/asm/issue/22911/245284 

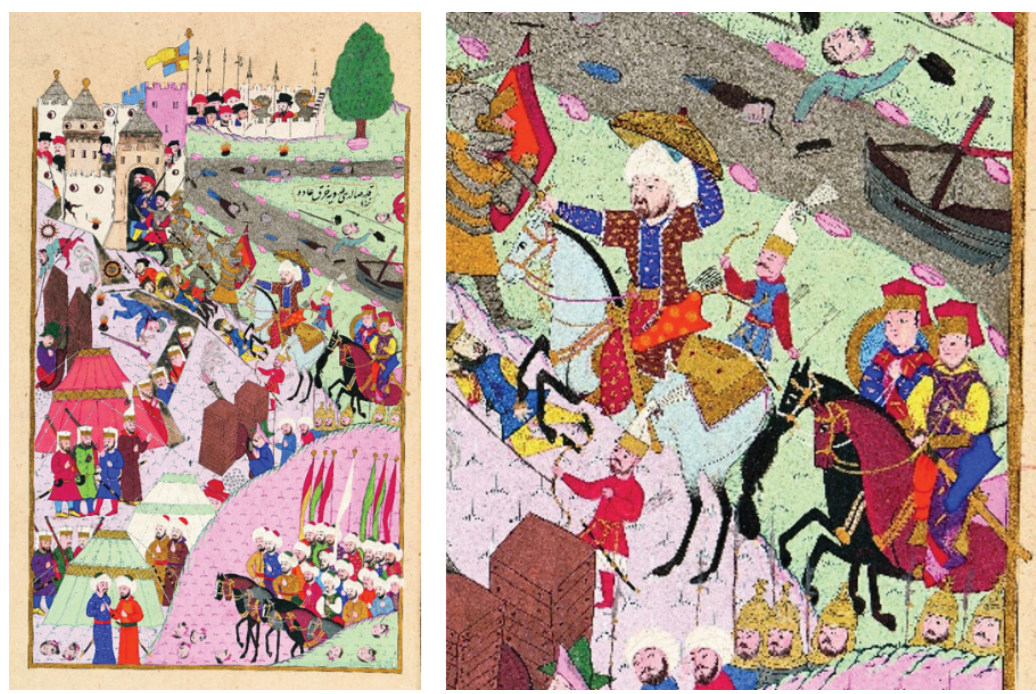

G. 13. Barça. Seyyid Lokman, Hünernâme I. TSM. H.1523, y.165a.

Seferlerle ilgili yazmalardan bir diğeri Keyfîyet-i Rûsiye (1710-1711)dir. Osmanlı ve Ruslar arasında Karadeniz'de gerçekleşen savaşları içermektedir. Bir bölümünü, sefere katılan Türk denizcisinin tuttuğu günlükler oluşturmaktadır ${ }^{74}$ ve minyatürleri mevcuttur. Bunlardan birinde; Şehbaz-1 Bahri kalyonu ve kabudan baştardası (G. 15), Akdeniz fırkatesi, Kızılhisarlı serasker Mustafa Bey firkatesi ${ }^{75}$ ve kancabaş (G. 16), general ve küffarın beş pare büyük geçidi (G. 17), küffar kayıkları ve aktarma ${ }^{76}$ (G. 18), küffar gider, Bozcaadalı gibi gemiler isimleriyle birlikte verilmiştir. Denizcinin, kıyıda yüze yakın düşman kayığı olduğu, Rus çadırlarının kıyıya yakın kurulduğu, siper oluşturulduğu, kancabaş ve fırkatelerin ayrı kollardan saldırdıkları, Kızılhisarlı Mustafa Bey ve Akdeniz firkatelerinin gemileri ele geçirdikleri, kancabaşların kıyıya yakın durdukları, suyun derinliğinin bilinmemesinden kalyon ve baştardanın geri planda kaldıkları gibi söylemleri, tasvirin İnceki Muharebesi’ ${ }^{7{ }^{77}}$ (G. 14) anlattığını ortaya koymaktadır. Ambarlı kalyonlar arasında değerlendirilen Şehbaz-1 Bahri’nin, 1737 Rus Harbi’ne katıldığı farklı kaynaklarda da geçmektedir. ${ }^{78}$ Minyatürde, Osmanlı donanmasının küffarınkini çember içine aldığını, Şehbaz-1 Bahri ve kabudan baştardasının kıyıdan uzak olduklarını, kancabaşların üst taraftan küffar gemilerini baskıladıklarını, kıyıdaki onlarca küffar kayıklarını, çadırlarını ve metrislerini gözlemlemek mümkündür.

74 İlhami Danış, “1736-1739 Savaşlarında Karadeniz’de Osmanlı Donanması,” (Yüksek Lisans tezi, İstanbul Üniversitesi, 2007), 58.

75 İnce donanma gemilerinden olup süratli hareket etmesi sebebiyle daha çok haber getirip götürme hizmetinde kullanılmıştır. bk. Bostan, "Gemi," 14.

76 Koruma görevi yapan gemilerden olup ince donanma grubunda yer alır. bk. Bostan, “Gemi,” 14.

77 İnceki Muharebesi için bk. Danış, 1736-1739 Savaşlarında Karadeniz’de Osmanlı Donanması, 68-71.

78 Mustafa Gürbüz Beydiz, “Osmanlı Minyatüründeki Gemibaş Figürleri,” VIII. Türk Deniz Ticareti Tarihi Sетроzуити, Marmara Üniversitesi (Mayıs 2016), İstanbul: İstanbul Yayınları, 2017), 57. 


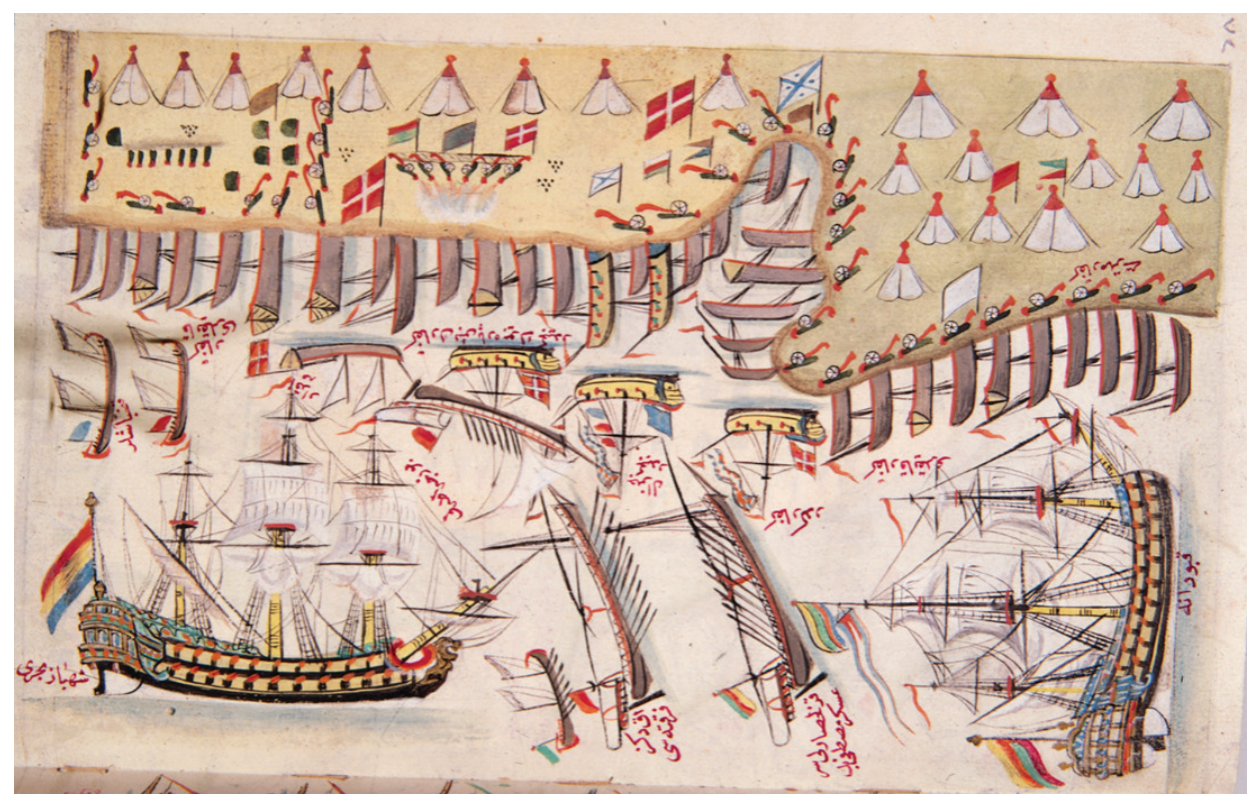

G. 14: Osmanlı gemi türleri, Keyfìyet-i Rûsiye TSM. H.1627
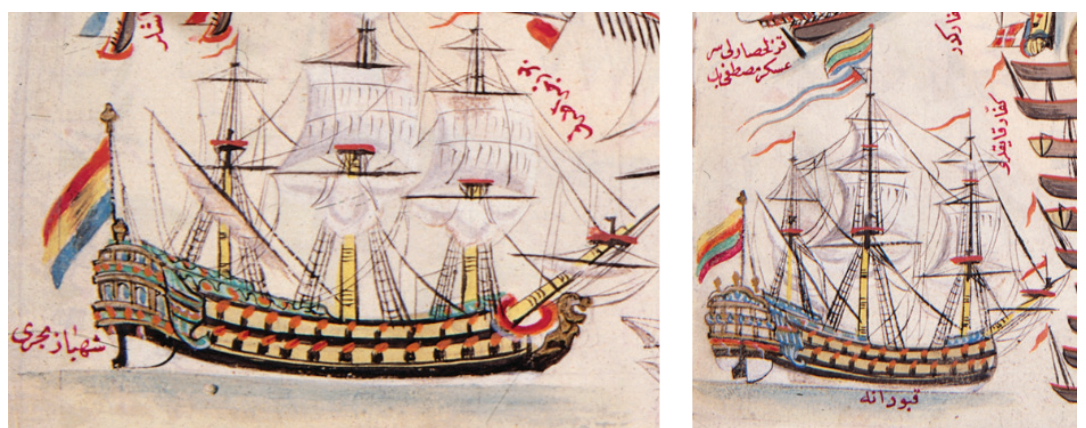

G. 15: Şehbaz-1 Bahri (sol) ve Kapudan Baştardası (sağ) (G. 14 detay)
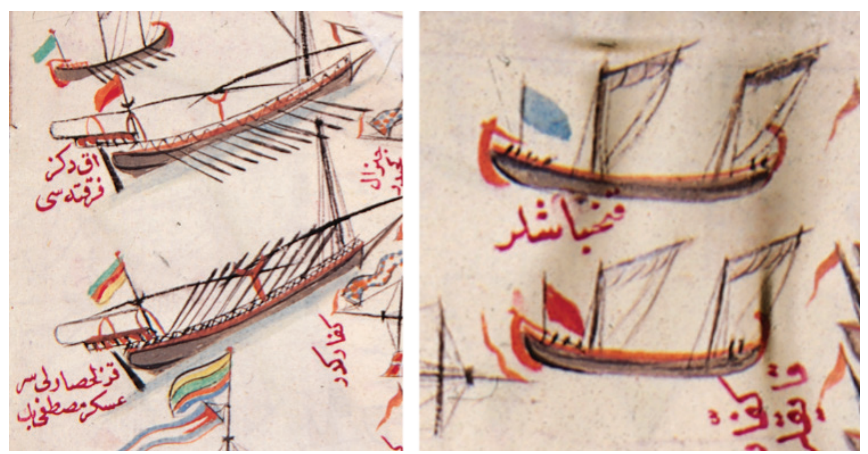

G. 16: Kız1lhisarlı serasker Mustafa Bey ve Akdeniz Fırkateleri (sol), Kancabaşlar (sağ) (G. 14 detay) 

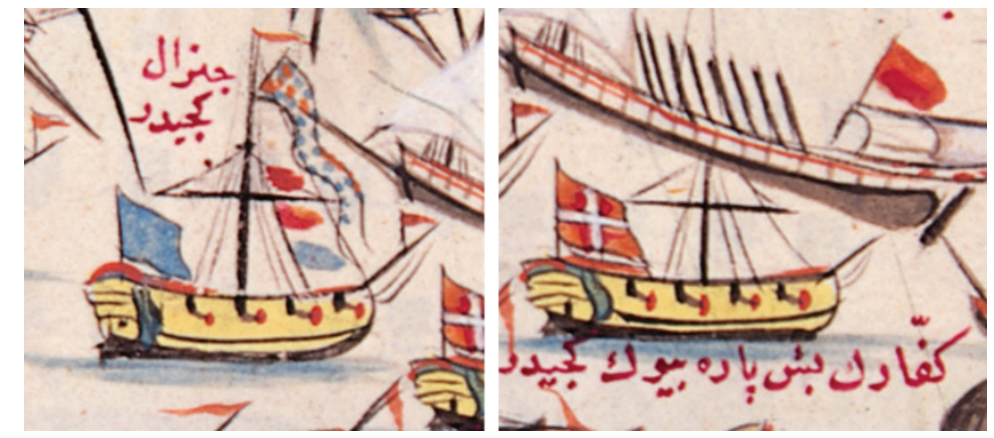

G. 17: General Geçidi (sol) ve Küffarın beş pare büyük geçidi (sağ) (G. 14 detay)
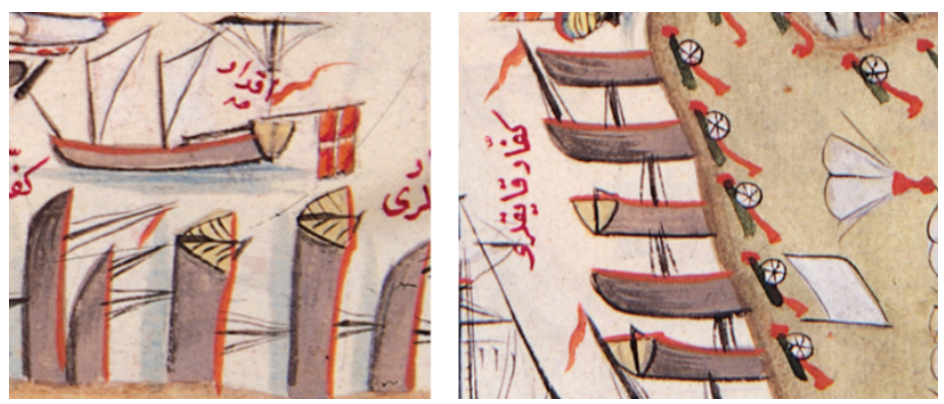

G. 18: Aktarma (sol) ve Küffarın kayıkları (sağ) (G. 14 detay)

\section{Sonuç}

Dünyaya hükmeden bir devlet olmayı hedefleyen Osmanlı, arzusunu gerçekleştirmek için askerî alanda sistemli bir politika izlemiş ve bu amaç doğrultusunda öncelikli olarak atlı akıncılardan müteşekkil birliklerin yerine düzenli bir ordu oluşturmuştur. Seferlerin başarıyla sonuçlanması için devletin tüm imkânları değerlendirilmiş ve ordunun gerek duyacağ 1 teçhizat temin edilmiştir. Askerin yorulmaması ve çarpışma anında tüm gücüyle savaşabilmesi için ihtiyaç dâhilindeki malzemelerin, çeşitli vasıtalarla sefer bölgesine sevk edilmesi sağlanmıştır. Bunu, tarihî kaynaklardaki bilgilerden ve Osmanlı sefer konulu minyatürlerden gözlemlemek mümkündür. Seferlere katılan nakkaşlar tarafından yapılan tasvirler, olay anını gerçekçi bir yaklaşımla sunmakta ve pek çok ayrıntı barındırmaktadır. Dönem seferlerini içeren minyatürler, taşımada farklı alternatiflerden istifade edildiğini sergilemektedir. Vasıta olarak en fazla kullanılan hayvan at olmakla birlikte, develer de hem binek olarak kullanılmış hem de yük taşımada değerlendirilen grubu oluşturmuştur. Az sayıda olsa da fillerin de seferlerde kullanıldığı anlaşılmaktadır. Devlet erkânının hastalık gibi zorunlu hâller dışında tekerlekli araba ya da tahtırevan gibi kullanmadığı, binek olarak atı tercih ettikleri görülmektedir. Kaynaklarda öküz ve mandanın, yük arabalarını çekmekte kullanıldığ 1 belirtilse de incelemiş olduğumuz örneklerde rastlanmamıştır. Deniz aşırı seferlerle birlikte farklı tip ve özelliklere sahip gemiler inşa edilmiş, bunlar da dönem teknolojisinin sunduğu imkânlar ve ihtiyaçlar doğrultusunda şekillenmiştir. 17. yüz- 
yılın sonuna kadar kürekli gemiler kullanılırken, bu tarihle birlikte yelkenli gemilere geçişin gerçekleştiği görülmektedir.

Sonuç olarak, Osmanlı Devleti'nin gerçekleştireceği seferlerde tercih ettiği vasıtaları, fethedilmesi planlanan bölgenin coğrafyası belirlemiştir. Bu husus gerek padişahlar gerekse üst düzey mevkilerde görev alan devlet adamları tarafından gerçekleştirilen seferlere katılan müelliflerin ortaya koydukları yazma eserlerden anlaşılmaktadır. Eserlerin içeriklerini anlaşılır kılmak adına bizzat sefere katılan nakkaşlar tarafından eklenen minyatürlerin de metinle birlikte değerlendirildiklerinde gerçekçi bir şekilde ele alındıklarını ve Osmanlı seferlerini konu alan yayınlarla örtüştüklerini söylemek mümkündür.

Hakem Değerlendirmesi: Diş bağımsız.

Çıkar Çatışması: Yazar çıkar çatışması bildirmemiştir.

Finansal Destek: Yazar bu çalışma için finansal destek almadığını beyan etmiştir.

Peer-review: Externally peer-reviewed.

Conflict of Interest: The author has no conflict of interest to declare.

Grant Support: The author declared that this study has received no financial support.

\section{Kaynakça/References}

Agoston, Gabor. “Top.” TDV İslam Ansiklopedisi. 41. İstanbul: Türkiye Diyanet Vakfı Yayınları, 2012, 240-242.

Agoston, Gabor. Osmanlı'da Savaş ve Serhad. Çev. K. Şakul. İstanbul: Timaş Yayınları, 2013.

Akpınar, Şerife. "Minyatürlerle Süslenmiş Manzum Bir Tarih: Şeh-nâme-i Nâdirî.” Divan Edebiyatı Araştırmaları Dergisi 23 (2019): 1-44.

Anafarta, Nigar. Hünernâme Minyatürleri ve Sanatçıları. İstanbul: Doğan Kardeş Matbaacılık, 1969.

And, Metin. Tasvir Sanatları I: Minyatür. İstanbul: Yapı Kredi Yayınları, 2014.

Aydın, Alperen Y. “Osmanlı Denizciliği (1700-1770).” Doktora tezi, İstanbul Üniversitesi, 2007.

Bağcı, Serpil, Filiz Çağman, Günsel Renda ve Zeren Tanındı. Osmanlı Resim Sanatı. Ankara: Kültür ve Turizm Bakanlı̆̆ Yayınları, 2012.

Beydiz, Mustafa G. "Osmanlı Minyatüründeki Gemibaş Figürleri.” VIII. Türk Deniz Ticareti Tarihi Sempozyumu (27-28 Mayıs 2016) Marmara Üniversitesi. İstanbul: İstanbul Yayınları, 2017, 51 60.

Beydiz, Mustafa G. Osmanlı Gemi Tasvirleri. İstanbul: Kabalcı Yayınevi, 2013.

Biçer, Aykut A. Klasik Dönem Osmanlı Kara Ordusunda Sefer Organizesi. Ankara: Yason Yayınları, 2014.

Bostan, İdris. “Gemi.” TDV İslam Ansiklopedisi. 14. İstanbul: Türkiye Diyanet Vakfı Yayınları, 1996, 11-15.

Bostan, İdris. “Kadırga'dan Kalyon'a.” The Journal of OttomanStudies XXIV (2004): 65-86.

Bostan, İdris. "Tersane-i Amire.” TDV İslam Ansiklopedisi. 40. İstanbul: Türkiye Diyanet Vakfi Yayınlar1, 2011, 513-516. 
Bostan, İdris. Beylikten İmparatorluğa Osmanlı Denizciliği. İstanbul: Kitap Yayınevi, 2007.

Börekçi, Günhan. Nüzhet-i Esrarü'l-Ahyar Der-Ahbar-ı Sefer-i Sigetvar. Haz. Ahmet Arslantürk ve Günhan Börekçi. İstanbul: Zeytinburnu Belediyesi Kültür Yayınları, 2012.

Börekçi, Günhan. "The Memory of Szigetvár and Sultan Süleyman in Ottoman/TurkishCulture.” The Battle for Central Europe. Ed. Pál Fodor. Leiden: Brill Pub., 2019, 523-538.

Canatar, Mehmet. "Muhasara." TDV Íslam Ansiklopedisi. 31. İstanbul: Türkiye Diyanet Vakfi Yayınları, 2006, 11-13.

Chester Beatty Digital Collections. Crossing the Bridge on the Drava, from the History of Sultan Süleyman by Sayyid Luqman. Erişim 20 Eylül 2020. https://viewer.cbl.ie/viewer/ object/T_413_60/2/LOG_0000/

Chester Beatty Digital Collections. History of Sultan Süleyman, "Süleyman's Body Escorted Back to Istanbul by the Ottoman Army, from the History of Sultan Süleyman by Sayyid Luqman." https://viewer.cbl.ie/viewer/image/T_413_113/2

Çavuş, Sinan. Süleymanname Tarih-i Feth-i Şikloş Estergon ve İstol(n)i Belgrad, İstanbul: Tarih Araştırmaları Dokümantasyon Merkezi Kurma ve Geliştirme Vakfı Yayınları, 1987.

Çırpan, Mustafa. “Osmanlı Devleti'nde Gemi Tipleri ve Gemi Kazaları ile İlgili Değerlendirmeler.” Gemi İnşaatı ve Deniz Bilimleri Dergisi 19 (2020): 41-58.

Çiçek, Kemal. “Osman Paşa, Özdemiroğlu.” TDV İslam Ansiklopedisi. 33. İstanbul: Türkiye Diyanet Vakfi Yayınları, 2007, 471-473.

Çoruhlu, Tülin. Osmanlı Tüfek, Tabanca ve Teçhizatları (Askerî Müzeden Örnekler). Ankara: Genelkurmay Basımevi, 1993.

Danış, İlhami. “1736-1739 Savaşlarında Karadeniz’de Osmanlı Donanması.” Yüksek Lisans tezi, İstanbul Üniversitesi, 2007.

Danişmend, Hami. İ. İzahlı Osmanlı Tarihi Kronolojisi. 4. İstanbul: Türkiye Yayınevi, 1947.

Doğan, Dilek. “16.-18. Yüzyıl Minyatürlerinde Osmanlı Arabaları.” Yüksek Lisans tezi, Marmara Üniversitesi, 2011.

Emecen, Feridun ve Erhan Afyoncu. Savaşın Sultanları I-II. Ed. Coşkun Yılmaz. İstanbul: Bilge Yayım, 2018.

Emecen, Feridun. "Mohaç Muharebesi.” TDV İslam Ansiklopedisi. 30. İstanbul: Türkiye Diyanet Vakfi Yayınları, 2005, 232-235.

Emecen, Feridun. "Niğbolu Savaş1.” TDV İslam Ansiklopedisi. 33. İstanbul: Türkiye Diyanet Vakfı Yayınlar1, 2007, 89-92.

Engin, Vahdettin. “Otomobil Öncesinde İstanbul'da Kara Ulaşımı.” Osmanlı İstanbulunda Otomobil. Ed. Erhan Afyoncu ve Coşkun Yılmaz. İstanbul: Türkiye Turing ve Otomobil Kurumu, t.y., 5981.

Erkmen, Emir S. "Klasik Dönem Osmanlı Kara Kuvvetleri (Silahları ve Teçhizatları).” Doktora tezi, Ankara Üniversitesi, 2019.

Eroğlu, Süleyman. “Âsafî’nin Şecâat-Nâme Mesnevisi.” Turkish Studies International Periodical For the Languages, Literature and History of Turkish or Turkic, 4/7, (2009): 253-297, DOI:http:// dx.doi.org/10.7827/TurkishStudies.908.

Ertaş, Yaşar M. “Osmanlı Devletinde Sefer Organizasyonu.” Osmanlı. 6. Ankara: Yeni Türkiye Yayınlar1, 1999, 590-597. 
Ertuğ, Zeynep Tarım. "Hünernâme.” TDV İslam Ansiklopedisi. 18. İstanbul: Türkiye Diyanet Vakfı Yayınları, 1998, 484-485.

Ertuğ, Zeynep Tarım. “Osmanlı Devleti'nde XVI. Yüzyıl Cülus ve Cenaze Törenleri.” Doktora tezi, İstanbul Üniversitesi, 1995.

Ertuğ, Zeynep Tarım. "The Depiction of Ceramonies in Ottoman Miniatures: Historical Recordor a Matter of Protocol." Muqarnas 27/1 (2010): 251-275.

Esin, Emel. “Türk Kültüründe At ve Atç1lık.” Türk Kültüründe At ve Çağdaş Atçılık. İstanbul: Resim Matbaac1lik, 1995, 54-90.

Fidannaz, Püryani. “İmparatorluğa Geçiş Sürecinde Osmanlı Denizciliği.” Uluslararası Sosyal Araştırmalar Dergisi 50 (2017): 215-222.

Genç, Serdar. "III. Ahmed Dönemi İran Seferlerinde Nakliyenin Sağlanması ve Nakliye Vasıtaları (1722-1725)." HistoryStudies 4/1 (2012): 235-249.

Göre, Zehra. “Âsafî Dal Mehmed Çelebi'nin Şecâ'at-Nâme'sinde Edebî Tasvirler.” Osmanlı Mirası Araştırmaları Dergisi 6/16 (2009): 401-431.

Halaçoğlu, Yusuf. “At,” TDV İslam Ansiklopedisi. 4. İstanbul: Türkiye Diyanet Vakfı Yayınları, 1991, 28-31.

İlgürel, Mücteba. “Osmanlı Topçuluğunun İlk Devirleri,” Prof. Dr. Hakkı Dursun Yıldız Armağanı. Ankara: Türk Tarih Kurumu Yayınları, 1995, 285-293.

İpşirli, Mehmet. “Araba.” TDV İslam Ansiklopedisi. 3. İstanbul: Türkiye Diyanet Vakfı Yayınları, 1991, 242-245.

Karagöz, Hakan. "Petervaradin Muharebesinde (1716) Habsburgların Osmanlılardan Ele Geçirdiği Silahlar ve Teçhizat." Tarih Dergisi 59 (2008): 79-112.

Kâtip Çelebi. Tuhfetü'l-Kibâr fì Esfâri'l-bihar. Çev. İdris Bostan. Ankara: TÜBA Yayınları, 2018.

K1lıçarslan, Yasemin. "Cebeci.” TDV İslam Ansiklopedisi. 7. İstanbul: Türkiye Diyanet Vakfı Yayınları, 1993, 182-183.

Kozalak, Kadir ve Tufan Gündüz. “II. Osman'ın Hotin Seferi (1621).” Ankara Üniversitesi Osmanlı Tarihi Araştırma ve Uygulama Merkezi Dergisi 14 (2003): 129-144.

Kurtaran, Uğur. “Osmanlı Seferlerinde Organizasyon ve Lojistik.” Turkish Studies 7/4 (2012): 2269-2286.

Mahir, Banu. Osmanlı Minyatür Sanatı. İstanbul: Kabalcı Yayınevi, 2012.

Murphey, Rhoads. Osmanlı'da Ordu ve Savaş (1500-1700). Çev. M. Tanju Akad. İstanbul: Homer Yayınevi, 2007.

Neşri, Mehmed. Kitâb-ı Cihan-NümaNeşrî Tarihi II. Haz. F. R. Unat ve A. Köymen. Ankara: Türk Tarih Kurumu Yayınları, 1987.

Özkoca, Adnan. “Türkiye'de At Yetiştiriciliği ve Sun'i Tohumlama Teknolojisi.” Türk

Kültüründe At ve Çağdaş Atçılık. Haz. Emine Gürsoy Naskali. İstanbul: Türkiye Jokey Kulübü Yayınlar1, 1995, 329-331.

Öztürk, Necdet. XV. Yüzyıl Tarihçilerinden Kemal, Selatin-nâme (1299-1490). İstanbul: Türk Tarih Kurumu Yayınları, 2008.

Pakalın, M. Zeki. Tarih Deyimleri ve Terimleri Sözlüğü 3. İstanbul: MEB Basımevi, 1972.

Parladır, Şebnem. "Sigetvar Seferi ve Nakkaş Osman.” Sanat Tarihi Dergisi XVI/1 (2007): 67-108.

Sağırlı, Abdurrahman. "Süleymannâme." TDV İslam Ansiklopedisi. 38. İstanbul: Türkiye Diyanet Vakfi Yayınları, 2010, 124-127. 
Sayyid Luqman, Hünername II, Crossing the Bridge on the Drava, from the History of Sultan Süleyman, T 413.60. Erişim 20 Eylül 2020. https://viewer.cbl.ie/viewer/object/T_413_60/2/ LOG_0000/

Sümer, Faruk. Türklerde Atçılık ve Binicilik. İstanbul: Türk Dünyası Araştırmaları Vakfı, 1983.

Şahsuvaroğlu, Haluk Y. "Barbaros'un Seferleri.” Tarihten Sayfalar. Taha Toros Arşivi. https://core. ac.uk/download/pdf/38326634.pdf, Erişim Tarihi: 12 Aralık 2020.

Tarakçı, Nejat. Deniz Gücünün Osmanlı Tarihi Üzerindeki Etkileri. İstanbul: Deniz Basımevi, 2009.

Turan, Osman. Türk Cihan Hâkimiyeti Mefkûresi Tarihi. İstanbul: Ötüken Yayınları, 2003.

Türkçe Sözlük 1-II. Ankara: Türk Dil Kurumu Yayınları, 1988.

Türkmen, İlhan. Fatih Sultan Mehmed Dönemi Surbistan Seferleri. AsiaMinorStudies3/5 (Ocak 2015): 114-134. https://dergipark.org.tr/tr/pub/asm/issue/22911/245284

Uzun, Mustafa İ. "Ganîzâde Mehmed Nâdirî”. TDV İslam Ansiklopedisi. 13. İstanbul: Türkiye Diyanet Vakfi Yayınları, 1996, 355-356.

Uzunçarşılı, İbrahim H. Osmanlı Devlet Teşkilatında Kapıkulu Ocakları II. Ankara: Türk Tarih Kurumu Yayınları, 1988.

Uzunçarşıllı, İbrahim H. Osmanlı Devletinin Merkez ve Bahriye Teşkilatı. Ankara: Türk Tarih Kurumu, 1988.

Yazıc1, Tahsin. "Fil.” TDV İslam Ansiklopedisi. 13. İstanbul: Türkiye Diyanet Vakfı Yayınları, 1996, 67-68.

Yıldız, Ersin. “Osmanlı Devleti'nin Sefer Organizasyonlarında Kullandığı Hayvanlar (XVI.- XVIII. Yüzy1llar).” Yüksek Lisans tezi, Ağr1 İbrahim Çeçen Üniversitesi, 2019.

Yurdaydın, Hüseyin G. "Matrakçı Nasuh.” TDV Íslam Ansiklopedisi. 28. Ankara: Türkiye Diyanet Vakfi Yayınları, 2003, 143-145. 
